\title{
LA OBLIGACIÓN DE RESCATAR CAUTIVOS Y LA ORDEN DE SANTIAGO (1517-1535)
}

\author{
POR \\ PEDRo ANDRÉs PorRAs ARBoledas ${ }^{1}$ \\ Universidad Complutense de Madrid, Facultad de Derecho
}

La libertad, Sancho, es uno de los más preciosos dones que a los hombres dieron los cielos; con ella no pueden

igualarse los tesoros que encierra la tierra ni el mar encubre; por la libertad así como por la honra se puede $y$ debe aventurar la vida, y, por el contrario, el cautiverio es el mayor mal que puede venir a los hombres. ${ }^{2}$

\section{RESUMEN}

Durante la primera mitad del reinado del Emperador Carlos la Orden de Santiago colaboró, tanto de forma pasiva como activa, en el rescate de cautivos cristianos retenidos en el norte de África; para ello contó con un fondo de ingresos eventuales con el que procuró atender sus obligaciones como instituto redentor, documentándose esto especialmente en 1525 y 1535.

PALABRAS CLAVE: Orden de Santiago; redención de cautivos; piratería; hospitales.

\section{THE OBLIGATION TO RESCUE CAPTIVES AND THE ORDER OF SANTIAGO (1517-1535)}

\section{ABSTRACT}

During the first half of the reign of the Emperor Carlos V the Order of Santiago contributed, so much of passive as active form, to the rescue of captive Christians retained in the north of Africa; for this intention it relied on a bottom of eventual income that it tried to attend to his obligations as redeeming institution, since it receives documents specially in 1525 and 1535.

KEY WORDS: Order of Santiago; redemption of captives; piracy; hospitals.

Cómo CITAR ESTE ARTícUlo / CITATION: Porras Arboledas, P. A. 2017. «La obligación de rescatar cautivos y la Orden de Santiago (1517-1535)». Hispania Sacra 69, 139: 195-219. doi: 10.3989/hs.2017.014

\section{Recibido/Received 14-02-2014 \\ Aceptado/Accepted 10-02-2016}

La Orden de Santiago, tanto en su faceta militar, como, sobre todo, en la religiosa, contaba entre sus obligaciones con la de practicar la guerra contra el infiel (básicamente, los musulmanes españoles) y, como consecuencia de los avatares de estos conflictos, la de sanar y recuperar a aquellos de sus miembros que hubieran resultado heridos o caído en cautividad. Durante los años de la Edad Media ambas actividades, sanatoria y redentora, se atribuyeron funcionalmente a los Hospitales con que contaba la Orden. ${ }^{3}$

\footnotetext{
1 pporras@der.ucm.es/ORCID iD: http://orcid org/0000-0002-2884-8519

2 Cervantes 1998: Segunda parte, cap. LVIII, 1.094.

3 La Orden contaba durante la baja Edad Media con cinco hospitales en la provincia de Castilla: Toledo, Talavera, Cuenca, Alarcón y Moya, éste último desaparecido a comienzos del siglo XIV; entre sus funciones principales se hallaba el rescate de freiles cautivos. A inicios
}

Al igual que sucedió cuando los comendadores dejaron

del siglo XVI dejaron de ser encomiendas y al frente de los mismos se colocaron dos clérigos en calidad de administradores, uno para los toledanos y otro para los conquenses (Porras Arboledas 1997: 144).

Sobre el Hospital toledano véase el reciente trabajo de Ángela Madrid (2014).

El Hospital de Mérida, primeramente situado en León, fue devuelto en 1600 a su emplazamiento inicial, por acuerdo del Capítulo general, quedando anejo al convento de San Marcos (Medrano 1627: tít. XII, cap. VII, fol. 116r). El Hospital de Villamartín, sito en el partido de Castilla Vieja, fue trasladado a Villasirga, a instancias del presidente del Consejo de Órdenes, conde de Osorno, durante el Capítulo de Valladolid de fecha indeterminada (1523 ó 1527) (Ibídem: tít. XIX, cap. IV, fol. 166r-166v).

En la época del maestre don Alonso de Cárdenas, ante el desorden existente en la administración de los comendadores de los hospitales, se estableció que los de Toledo, Cuenca y Alarcón redimiesen cada uno al año un cautivo y, en adelante, destinasen, respectivamente, 10.000, 
de mantener hombres a caballo que sirvieran bajo su estandarte -en que se les obligó a redimir en metálico esa obligación, mediante la asignación de un número determinado de lanzas en función del volumen de las rentas de cada encomienda-, los hospitales de la Orden se vieron abocados a destinar una parte de sus ingresos ordinarios a la redención de cautivos, en tanto que sus funciones sanitarias se especializaban en distintas enfermedades: el Hospital toledano de Santiago de los Caballeros, por ejemplo, se centró, al menos, desde fines del siglo XV en el tratamiento del mal de bubas, esto es, en cuadros infecciosos de origen sexual, en concreto, la sífilis.

Se ha escrito que durante los años finales del siglo xv y los iniciales del siguiente las órdenes religiosas especializadas en los menesteres de redención de cautivos, es decir, mercedarios ${ }^{4}$ y trinitarios, tuvieron escasa intervención en este campo, y que la de la Orden de Santiago fue nula. ${ }^{5}$ Desde luego, considerando el curriculum que consta en el haber de todas estas instituciones para tiempos posteriores, resulta difícil estar de acuerdo con esa afirmación, pudiendo atribuirse esa impresión a la ausencia de documentación que avale el papel de estos religiosos en labor tan meritoria a los ojos de Dios, a tenor de la mentalidad de la época. ${ }^{6}$ Por mi parte, en el presente estudio pretendo dar a conocer las labores realizadas, tanto de forma activa como pasiva, por la Orden santiaguista en el ámbito de la redención de cautivos, a partir de la documentación conservada en el Registro General del Sello de la Orden, para los primeros años en que se conservan provisiones seriadas. En ocasiones, como se verá, la Orden colaborará con comendadores mercedarios. Intentaré aportar datos procedentes de archivos granadinos (Chancillería y Protocolos), que vienen a redondear los extraídos del ámbito de la Orden.

Como decía, las labores redentoras de la Orden podían tener tanto carácter activo como pasivo. Comenzando por éstas últimas, el Consejo de Órdenes podía conceder licencia a particulares, tanto vasallos suyos, como foráneos - ésta sería la mayoría -, para deambular por los territorios de los tres institutos durante un período de un año recaudando las limosnas que los fieles tuvieran a bien concederles.

otros tantos y 5.000 mrs. a ese mismo fin cada año (Ibídem: tít. XIX, cap. I, fol. 164v-165r).

4 Véase mi reciente trabajo: Porras Arboledas 2015.

5 López de Coca 1978: 283.

Sin ánimo de construir aquí una nota bibliográfica, sí merece la pena citar, al menos, López de Coca 1997: 391-408; así como la obra de González Arévalo 2004 o las obras recogidas en el trabajo colectivo, editado por Martínez Torres (ed.) 2008. Si hubiera de construirla, habría de citar, además, diversas obras de J.F. Jiménez Alcázar, F. Andújar, B. Vincent, A.L. Molina Molina, L. Maziane, E. Cabrera Muñoz, M.A. de Bunes o F.J. Díaz González, que se han ocupado largo y tendido de estos temas; en especial, me referiría al trasunto de la tesis doctoral de Martínez Torres 2004, o a los de la tesis de González Arévalo (2006a y 2006b), sobre la esclavitud y el cautiverio en Málaga a fines de la Edad Media.

6 Hoy en día todo este universo de circunstancias nos parece como algo remoto y desprovisto de toda emoción, pero hasta el sujeto más inmerso en la vulgaridad de nuestros días es capaz de atisbar los sentimientos que embargaban a los cristianos capturados en tierras infieles leyendo las memorables páginas dejadas por Miguel de Cervantes, con su magistral canto a la libertad, recogido en su obra maestra. Naturalmente, no seríamos hombres de nuestro tiempo si no predicáramos exactamente lo mismo para los musulmanes cautivos en tierras de la Cristiandad.
Sabemos que esta forma de caridad pasiva fue una realidad durante el bienio 1528-1530, es posible que como respuesta al recrudecimiento de la piratería berberisca y, luego, turca, tras el fallido intento de tomar el Peñón de Vélez de la Gomera, en 1525 . $^{7}$ En este caso la Orden se limitaba a tolerar que durante un corto período de tiempo los parientes de los cautivos, cuando no éstos mismos, consiguiesen fondos para atender a los rescates devengados. Esto suponía el riesgo de encontrarse con la enemiga de los clérigos de cada localidad, que veían disminuir de ese modo el fondo de caridad disponible entre sus fieles, ${ }^{8}$ pero, por lo demás, no suponía una actividad positiva - proactiva, diríamos hoyni un desembolso achacable al haber de las Órdenes.

Algo relativamente parecido puede decirse con respecto a las bulas de la Santísima Trinidad para redención de cautivos, predicadas por los trinitarios a fin, así mismo, de allegar fondos para sus actividades redentoras. Contamos con varios datos de 1526 que indican la oposición de los clérigos santiaguistas a la predicación de esa bula si no se les entregaba a ellos la cuarta parte de la recaudación, lo que, según ellos, era costumbre guardada en lo referente a la predicación de bulas, indulgencias y gracias destinadas a la Cruzada. ${ }^{9}$ El problema se planteó primero en la vicaría de Beas y luego en las de Segura y Yeste, así como en el priorato de San Marcos de León. ${ }^{10}$ En el priorato de Uclés la cuestión se demoró hasta el mes de julio, cuando el prior ordenó que no se detrajese cantidad alguna de dichas bulas. ${ }^{11}$ Sospecho que debió de ser el monarca el que ordenó que no se desviase parte alguna de la recaudación de esa bula, ante la imperiosa necesidad de contar con el mayor volumen posible de dinero para rescatar a aquellos de sus vasallos que habían sido hechos prisioneros en el fallido asalto al mencionado Peñón.

Sin embargo, el problema de la resistencia de los clérigos santiaguistas a renunciar a su participación en las bulas se vuelve a manifestar en 1530: en este caso, los documentos

7 Sobre el Peñón de Vélez de la Gomera en esos años, López de Coca 1993. Sobre la mencionada política del Consejo de Órdenes, Porras Arboledas 2014.

Describe tanto la pérdida del Peñón en 1520, someramente, como su reconquista definitiva, en 06/09/1564, Juan Ginés de Sepúlveda (1998: 106-111).

8 Para muestra vale un botón: en 1545 pleiteaban el concejo y el párroco de Villanueva de Alcardete por la costumbre que tenían en el pueblo de andar pidiendo limosna por las calles los cogedores municipales, llevándose lo recaudado en forma de pan a la parroquia el Día de Difuntos, tras lo cual se repartía entre los pobres vergonzantes de la localidad (Archivo Histórico Nacional, Órdenes Militares, Archivo Histórico de Toledo [en adelante, AHT], leg. 15.434).

9 Sobre estas bulas véase el reciente trabajo de Eugenio Serrano y Miguel F. Gómez Vozmediano (2013).

10 El vicario de Beas, Luis de Tamayo, se había quejado de que el provisor del obispado de Cartagena le había prohibido llevar parte alguna de dichas bulas, contra la costumbre. El Consejo dictó una circular para las tres vicarías segureñas, ordenando a los concejos de las mismas consignar en depositario el producto de la cuarta de las bulas de redención hasta nueva orden. Otra similar se remitió el día 30 al prior de San Marcos, ante la queja presentada por Pedro de Porras, cura de Calzadilla (AHT, leg. 78.112).

11 Alegaban en todos los casos los curas del territorio que su sustentación dependía en buena medida del cobro de su participación en esas bulas, indulgencias y gracias (AHT, leg. 78.115). El mandamiento de tener en depósito la porción en litigio se volvió a repetir en este priorato en diciembre del mismo año (AHT, leg. 78.122). 
conservados focalizan la contestación a estas medidas en el Campo de Montiel; de nuevo se quejaban los freiles, tanto vicarios como curas párrocos, de que sus ingresos ordinarios eran tan magros que difícilmente podrían mantenerse sin sus participaciones en el cobro de las bulas predicadas en sus sedes. Cuando se planteó el tema en febrero, la respuesta del Consejo de Órdenes fue, de nuevo, consignar en depositario esas porciones. ${ }^{12}$ Sin embargo, en esta ocasión, ya a fines de año, se ordenó que se entregase a los freiles lo que reclamaban, si bien debían constituir fianzas apropiadas de devolverlo si se fallaba en contra de sus intereses. ${ }^{13}$ Se ve que el caso se estaba dilatando en exceso ante los tribunales eclesiásticos.

También la orden de la Merced predicaba sus propias bulas, con la misma finalidad que los trinitarios; tan sólo contamos con un dato, que nos ilustra magníficamente de la problemática que se estaba viviendo en Castilla allá por 1526. El Lcdo. Diego García Calderón y los bachilleres Pedro García del Corro y Rodrigo Ponce habían expuesto ante el Consejo que ellos tuvieron cargo de predicar las bulas de la Santísima Trinidad para redención de cautivos en las provincias de la Orden; al tiempo de tomar dicha predicación, asentaron con el tesorero de dicha indulgencia que les pagaría para su mantenimiento y trabajo $6 \mathrm{mrs}$. por cada una de las bulas tomadas, pues estando predicándose entonces las bulas de Nuestra Señora de la Merced, se tomarían pocas de ambas; para evitarlo, estando en la predicación de la provincia de León, se concertaron con Ruy García de Meneses, tesorero de las bulas de la Merced, para que los predicadores no se superpusiesen en los mismos lugares al mismo tiempo, bajo ciertas penas, y que los de la Merced no predicasen las de la redención; los predicadores de la Merced y su tesorero no habían cumplido el acuerdo, causándoles a ellos pérdidas por valor de 100.000 mrs., habiendo incurrido en las penas del acuerdo. ${ }^{14}$ Una vez más se comprueba la premura con que se intentaba allegar dinero a la mayor brevedad para rescatar cautivos.

Tampoco parece que la Orden de Santiago fuera en el caso de la predicación de las bulas sino un espectador pasivo, aun en mayor grado que en el supuesto de las licencias para pedir limosna. ${ }^{15}$

No obstante, la Orden no podía sino hacer honor a su trayectoria histórica en estos graves asuntos. Un remedio que en nada comprometía los recursos propios de la institución era el de destinar a la redención de cautivos el producto de distintas penas pecuniarias impuestas

12 La misma providencia se tomó tanto para el partido de Mancha y Ribera de Tajo como en la zona dependiente del obispado de Cartagena, esto es, en toda la provincia de Castilla (AHT, leg. 78.158).

13 Se conservan los mandamientos librados en este sentido al vicario y curas del Campo de Montiel, en 27 de octubre (AHT, leg. 78.166), a Alonso Cano, cura de la parroquia de Santiago, y a Francisco de Santisteban, cura de la parroquia de San Miguel, ambas en Santa Cruz de la Zarza, en 26 de noviembre (AHT, leg. 78.167), y al cura del Corral de Almaguer, en dos de diciembre (AHT, leg. 78.168).

14 El 15 de junio el Consejo decidió cometer la resolución del caso al prior de San Marcos de León o a su provisor (AHT, leg. 78.114).

15 Pasados algunos años, será el propio monarca quien imponga a sus súbditos la prestación de limosnas obligatorias, como sucedió en 1558 para el socorro de Bugía (AHT, leg. 24.704). Se continuaba con la recaudación de la limosna, aunque la plaza había caído en 1555 (Alonso Acero 2000: 441). por el Consejo a sus freiles, caballeros y comendadores. ${ }^{16}$ Ahora bien ¿cuáles eran las infracciones que llevaban aparejada este tipo de penitencia y qué volumen de recaudación produjeron? Si respecto al primer punto, estoy en condiciones de aportar algunos datos, en lo relativo al segundo es imposible siquiera hacer una aproximación por falta de datos. En realidad, la información que nos ha llegado tan sólo se refiere, mayoritariamente, a las penas con que se les amenazaba en caso de que incumplieran un mandato expreso del Consejo. Veamos el listado disponible, organizado de menor a mayor cantidad:

\section{5 ducados}

(1526: al comendador del Horcajo, penitencia por no haber pedido licencia para poseer ni para confesar) (AHT, leg. 78.113).

\section{0 ducados}

(1517: al vicario de Caravaca para que cumpla mandato de no innovar en el caso de las andas del Corpus Christi ni en el exponer la Veracruz) (AHT, leg. 78.003).

(1526: al cura de Villamanrique para que cumpla mandato sobre las limosnas para las Ánimas del Purgatorio) (AHT, leg. 78.112).

(1527: al cura de Moratalla para que cumpla arancel de misas y oficios divinos) (AHT, leg. 78.123).

(1528: al comendador del Campo de Criptana para que abone condena por causa criminal) (AHT, leg. 78.125).

\section{0 ducados}

(1517: al vicario de Mérida que cumpla lo ordenado acerca de los delincuentes que se refugiaban en sagrado) (AHT, leg. 78.006).

(1518: al vicario de Mérida que cumpla lo ordenado acerca de los delincuentes que resumían corona) (AHT, leg. 78.015).

(1520: al comendador de Villanueva de la Fuente para que no saque causa de la Orden fuera de su jurisdicción) (AHT, leg. 78.039).

(1524: al adelantado de Granada, caballero de la Orden, para que entregue esa cantidad) (AHT, leg. 78.094).

(1526: al caballero íñigo López de Perea para que abone al prior de Uclés el diezmo de sus ganados) (AHT, leg. 78.109).

(1526: al cura de Colmenar de Oreja para que no entre en Pozuelo de Belmonte hasta tanto se sustancie cierta causa) (AHT, leg. 78.117).

16 Como repiten los documentos maestrales, la Orden castigaba a los contraventores de sus mandatos, si fueran seglares, dirigiéndose contra sus personas y bienes, en tanto que las gentes de la propia Orden serían castigadas por el maestre «con Dios y con Orden»; con esta expresión se refieren, respectivamente, a las penitencias espirituales -retiro a convento durante una temporada- y a las pecuniarias, en función de los recursos del penitenciado, cabiendo, además, la posibilidad de ser destinado a servir al Rey a la ciudad de Orán, sin sueldo, como le ocurrió al caballero Pedro Ruiz de la Mota, hijo del comendador de Montijo, condenado a penitencia de dos años en el convento de Uclés y servicio de 5 años en Orán, por haberse casado sin licencia y por haber librado distintas letras de cambio en fraude de sus acreedores, en 1538 (AHT, expte. 78.293).

El destino de esas cantidades variaba de acuerdo con los deseos de la Orden, así, en el período que estamos considerando, solían destinarse a la redención de cautivos, pero en años posteriores solían invertirse bien en obras pías, en general, bien, particularmente, en las numerosas construcciones de conventos nuevos o traslado de los mismos que se acometieron. 
200 ducados

(1522: al freile comisionado para colar la encomienda de Ocaña, si no dio traslado de la misma en 20 días al depositario de la media annata de dicha encomienda) (AHT, leg. 78.048).

(1526: al prior de San Marcos de León para que tenga a buen recaudo a homicidas) (AHT, leg. 78.110).

\section{0 ducados}

(1524: al caballero García Osorio para que no saque causa de la Orden fuera de su jurisdicción) (AHT, leg. 78.086 y 78.087$)$.

\section{0 ducados}

(1524: al comendador de Estremera si no compareciera a juicio criminal) (AHT, leg. 78.087).

(1526: al caballero Gómez Mexía de Figueroa para que rinda su residencia personalmente como corregidor de Jerez de los Caballeros) (AHT, leg. 78.111, mal colocada).

\subsection{0 ducados}

(1524: al caballero Valencia de Benavides para que comparezca a juicio criminal cuando se le convoque) (AHT, leg. 78.089).

(1525: al caballero Valencia de Benavides para que comparezca a juicio criminal, por haber violado condición de la libertad) (AHT, leg. 78.099).

(1525: al caballero Día Sánchez de Carvajal para que no saque causa de la Orden fuera de su jurisdicción) (AHT, leg. 78.101).

(1525: al caballero Valencia de Benavides para que no entre en Baeza y mantenga carcelería en la Corte) (AHT, leg. 78.104).

(1539: al caballero Ruy Gómez de Ayala para que cumplan él y los suyos seguro a favor de Alonso de San Pedro) (AHT, leg. 78.268).

\subsection{0 ducados}

(1525: al caballero Valencia de Benavides para que comparezca en causa criminal) (AHT, leg. 78.102).

3.000 ducados

(1524: al conde de Monteagudo, caballero de la Orden, por haber reincidido en amancebamiento con una dama) (AHT, leg. 78. 094).

Rentas de sus beneficios

(1522: a tres freiles comuneros del convento de San Marcos, condenados a estar un año en penitencia y a suspensión de la renta de sus beneficios, que destinaban a la redención de cautivos) (AHT, leg. 78.045).

Como se puede apreciar, la horquilla de valores de la penitencia pecuniaria es muy amplia, yendo de los 5 a los 3.000 ducados. Dado que se trataba de penas arbitrarias -en el sentido de que quedaba a la decisión del Consejo o, en su caso, del Capítulo general de la Orden, la graduación de las mismas, no de que se actuara con arbitrariedad-no es fácil encontrar un patrón en la imposición de estas penas, si bien deben barajarse dos motivaciones: la gravedad del hecho a prevenir o a castigar y, muy especialmente, la capacidad económica del destinatario del mandamiento en cuestión, como ya he mostrado en otro lugar. ${ }^{17}$ Llama la atención que el grueso de las admoniciones conservadas se refieran a los

\footnotetext{
17 Porras Arboledas 2013.
}

años 1524-1526, como si detrás de estos datos hubiese una política consciente por parte de la Orden; pero se trata tan sólo de una conjetura. En cualquier caso, sí que me consta que una parte de las penitencias pecuniarias recaudadas durante el Capítulo general de Valladolid de 1523 se destinó a la redención de cautivos. ${ }^{18}$ Algo que pudo repetirse en la siguiente reunión, tenida en la misma villa cuatro años más tarde, y en la de Madrid de 1535.

Quiere decirse con ello que la Orden contaba con un fondo disponible -pero de ingresos de carácter eventualpara estos fines, que era administrado por el Consejo de Órdenes; así mismo, contaba con las cantidades detraídas de las rentas de sus Hospitales para ese mismo fin y, por supuesto, le asistían los fondos que tanto los miembros del Consejo como otras personas de relieve social podían destinar al mismo fin en coyunturas determinadas.

Desgranemos cronológicamente los datos conservados sobre pagos de rescates: el más antiguo tiene lugar a mediados de mayo de 1522 cuando el Consejo dio a su contador, Sancho de Paz, mandamiento de pago de $9.000 \mathrm{mrs}$. a favor de Francisco el Lobo, vecino de Llerena, para rescatar a su hijo, del mismo nombre, que llevaba tres años cautivo en África; se le concedía como ayuda, ya que el total del rescate era superior, una vez comprobado que carecía de recursos para liberarse y que era vasallo de la Orden. Haría efectivo en Llerena el pago Pedro de Martín, hacedor del contador. Apenas quince días más tarde el Consejo acordó encargar al gobernador de la provincia de León que recibiera fianzas del padre del chico a fin de que invirtiera correctamente el dinero donado para efectuar el rescate, debiendo presentar luego ante el mismo Consejo al muchacho rescatado. ${ }^{19} \mathrm{Da}$ la impresión, a tenor de la actitud del Consejo, de que no estaban muy habituados a estas actividades.

En el verano de 1524, de acuerdo con dos minutas de consultas presentadas al presidente del Consejo -en ausencia del Emperador-, sabemos que don Beltrán de la Cueva se interesó por la suerte de dos encomendados suyos, los vecinos de Bedmar, Cristóbal Dorador y Bartolomé de Biedma, pidiendo «se les dé para ayuda a su rescate, que es muy crescido»; se dio a cada uno 15.000 mrs. Por su parte, Francisca Galíndez, vecina de Cádiz, reclamaba se le diese una ayuda para completar las 1.800 doblas que necesitaba para rescatar a unos hijos y criados suyos, cautivados por los moros de allende. Al parecer, se acordó darle limosna de 50.000 mrs. ${ }^{20}$ Efectivamente, dos meses más tarde el Consejo encomendaba al gobernador de la provincia leonesa que hiciese entrega de esa cantidad a Francisca, viuda del regidor gaditano Bartolomé Estupiñán, ${ }^{21}$ para ayuda al

18 En 1524 se daba comisión a don Diego de Córdoba, comendador de Alcuéscar y gobernador de la provincia de León, para recaudar dichas penitencias en su demarcación, que se habían destinado a la redención de cautivos (AHT, leg. 78.094).

19 El mandamiento de pago en 16 de mayo (AHT, leg. 89.065) y el mandamiento al gobernador en 2 de junio (AHT, leg. 78.066).

20 La petición del comendador de Bedmar en borrador de julio (AHT, leg. 78.091) y la de la gaditana en borrador de agosto (AHT, leg. 78.092).

21 Probablemente se trate del mismo Bartolomé Estupiñán Cabeza de Vaca, que tomó parte en la conquista de las Canarias. Sobre este linaje de la oligarquía gaditana, Bustos Rodríguez 1992: 175-176.

La muerte en hechos de guerra de tenedores de regidurías no dejaron de plantear problemas a sus sucesores, como lo muestra el caso de 
rescate de ella misma, de sus hijos y sobrinos, Melchor y Juana de Sagarraga, Isabel de Escaño, Inés de Mesa y Juan de Estupiñán. ${ }^{22}$ Este rescate debió de causar cierta impresión entre los mandatarios de la Orden, por cuanto se vuelve sobre ello en meses posteriores, así, en julio de 1525 se daba orden al gobernador don Diego de Córdoba para que entregase al monasterio de Santiago de la Espada de Sevilla el remanente del dinero que se le había ordenado recaudar. En efecto, le habían comisionado para cobrar $70.500 \mathrm{mrs}$. de las penitencias impuestas en el Capítulo de 1523 a comendadores de su provincia, de los cuales $50.000 \mathrm{mrs}$. se dieron a la viuda de Estupiñán, 12.750 mrs. se destinaron al monasterio de San Pablo de Valladolid y quedaban en su poder $7.850 \mathrm{mrs}^{23}$ La solemnidad final del caso tuvo lugar en Cádiz, cuando el 28 de agosto de 1525, en casa de los Estupiñán, ante Diego González, escribano público, compareció Francisca y le pidió que le diera testimonio de

cómo Melchior Estopiñán, su hijo, regidor desta cibdad, e Juan de Estopiñán, su sobryno, e Ynés de Mesa, su pryma, e Juana de Sagarraga e Ysabel d'Escaño, sus hijas, están en esta cibdad e en las dichas casas, porque agora son venidos e salidos de cativerio, pues fueron catibos por los moros en la Ysla de la Puente de León. ${ }^{24}$

En los inicios de 1525 se realizó una información sobre lo ocurrido con el rescate de Domingo Izquierdo, vecino de Motril: declaró bajo juramento Francisco Díaz, freile de la Orden, cura del Corral de Almaguer y administrador de los Hospitales de Santiago de los Caballeros de Toledo y de Talavera, que había ayudado a éste con limosna de 75 onzas de plata, pero que «desde Málaga se le fue, aviendo jurado de no se apartar d'él hasta que fuese presentado a S.M., y pidió que se resciba juramento de algunos dellos que trae rescatados sy es verdad lo susodicho». Así lo atestiguaron Juan Ramos, vecino de Almería, y Rodrigo de Ávila, corregidor de Málaga. ${ }^{25}$

Antón Martín, regidor de Vejer de la Frontera, fallecido en pelea con los turcos, según ejecutoria de 25/09/1537: ejecutoria a petición de Antón y Alonso de Osuna, vecinos de Vejer, contra el duque de Medina Sidonia, don Alonso Pérez de Guzmán, y Álvaro Hernández menor, también vecino: el 15 de abril de ese año se había leído por el alcalde mayor ante el cabildo municipal una carta del duque, en que expuso que «por parte de Álvaro Hernández, hijo de Antón Martín, regidor que fue desa my villa de Vejer, me fue fecha relación diziendo que yo, tinyendo consideración a qu'el dicho su padre murió en servicio de Dios e myo, peleando contra los Turcos, enemigos de nuestra Santa Fee Católica, e a los servicios que me avía fecho, fizo merced del oficio del regimiento del dicho su padre a Hernando Mingues, hijo menor del dicho Antón Martín, su padre, e que por no ser él de hedad, lo usase en su nonbre Alonso de Osuna, vezino desa dicha my villa, en lo qual él avya sydo por muy agraviado, porque, syendo hijo ligítimo e mayor del dicho Antón Martín e syendo ábil e subficiente para ello, de hedad convynyente, hera justo hazerle a él merced del dicho regimiento», por ello nombró para ello a Álvaro. Oidores, Dr. Peñas. Ramírez de Alarcón. Dr. Miguel de Ribera (Archivo de la Real Chancillería de Granada [en adelante, ARChG], leg. 5.621).

22 Mandamiento de pago a don Diego de Córdoba, comendador de Alcuéscar y gobernador de la provincia, de 17 de octubre (AHT, leg. 78.094).

23 Mandamiento de 21 de julio (AHT, leg. 78.103).

24 Fueron testigos Rodrigo de Mesa, vecino de Jerez de la Frontera, y Antón de Grajeda, vecino de Cádiz (AHT, leg. 78.104). El lugar del apresamiento, por tanto, fue la antigua Isla de León.

25 Fueron testigos del expediente los freiles de la Orden, Gómez de Tévar, vicario de Montiel, y Esteban Salido, cura de Terrinches, as como los porteros del Consejo, Bolea y Hernando de Valdés (AHT, leg. 78.146, mal colocada; debería estar en leg. 78.097).
Realmente, la pérdida del Peñón de Vélez de la Gomera en 1520 había recrudecido la actividad pirática desde ese lugar, como lo demuestran las cuentas rendidas en enero de 1525 por el mencionado Francisco Díaz, que anduvo rescatando 45 cautivos en el Peñón en los meses finales del año anterior. ${ }^{26} \mathrm{El}$ mismo freile fue requerido poco después por el Consejo para que se informase sobre el caso de los hijos de Mari Pérez de Villandrando: ésta tenía tres hijos cautivos en territorio marroquí; en concreto, su hijo Gaspar estaba en Taçora, donde el freile se había igualado con su propietario en 200 ducados, habiendo comprometido Francisco limosna de 80 onzas de plata para ayuda a su rescate; no se había llegado a buen fin, pues el freile no entregó dicha cantidad, por lo que la madre solicitaba que se le hiciese efectivo, pues contaba con el dinero restante para efectuar la liberación de al menos éste de sus hijos. ${ }^{27}$ Por una provisión posterior sabemos que Mari era viuda del alcaide Martín de Busto y vecina de Almagro; finalmente se le abonaron del dinero de los hospitales santiaguistas 12,5 ducados para ayuda al rescate de su hijo Baltasar de Busto. ${ }^{28}$

A partir de septiembre de 1525, cuando tuvo lugar el desastre del desembarco del marqués de Mondéjar en el Peñón de Vélez de la Gomera, las noticias sobre fallecidos y cautivos andaluces en dicho desbarato se multiplican en las fuentes, aunque no probablemente con la densidad que debieron alcanzar en la realidad. Así, en diciembre de ese año encontramos a un Juan de [¿Corme?], que

...dize que él e otras nueve personas fueron captivos en casa de Moley Abraén, e que el dicho su amo lo soltó a él para que truxese una carta a S.M. que le fiziese merced de un moro que está preso en la Santa Ynquisyción e que si lo llebase lo soltaría a él e a los otros nueve, e que el arçobispo de Sevilla dize que el dicho moro se dio a don Antonio de la Cueva para rescate de un hijo suyo. Suplica se le haga merced de alguna limosna para su rescate e de sus conpañeros. ${ }^{29}$

En realidad, el tal Corme no era otro que Juan de Orive, vecino de Tarifa, que aparece reflejado en una provisión de dos meses más tarde: el Consejo de Órdenes ordenaba a las justicias de Tarifa, Puerto de Santa María y otras localidades no especificadas que, personalmente, se informasen de la petición de varios de sus vecinos para rescatarse; se trataba de Juan de Orive, por sí y en representación de Ginés de Alicante, vecino de Almería, Antón Sánchez, vecino de Cádiz, Alonso de Burgos, natural de Burgos, Melchor Díaz, Lorenzo Hernández, Antonio González, Martín Alonso, Gaspar Hernández y Martín Vázquez, vecinos y habitantes del Puerto de Santa María. Se les encomendaba recabar

26 Rendición de cuentas en 26 de enero (AHT, leg. 78.097); transcripción de la cuenta en Apéndice (doc. 1). Gloso su contenido páginas adelante. En 12 de noviembre de 1526 se libró carta de pago al citado freile para que abonase al contador Sancho de Paz los 90.336 mrs. de que había sido alcanzado por las cantidades a pagar para redención de cautivos, sobre las rentas de sus hospitales, del período 1523-1526 (AHT, leg. 78.239; mal colocada).

27 Comisión informativa al freile, de 21 de julio (AHT, leg. 78.099).

28 Mandamiento de pago al contador Sancho de Paz en 10 de noviembre de 1526 (AHT, leg. 78.239; mal colocada).

29 Incluido en minuta para consulta al comendador mayor de Castilla y presidente del Consejo, en borrador de provisión de esa fecha (AHT, leg. 78.108). La lectura del apellido del peticionario no resulta fácil. 
información sobre si estaban cautivos en manos de moros, cuánto tiempo llevaban cautivos, dónde lo estaban, en poder de quiénes estaban, qué bienes tenía cada uno, qué podían valer esos bienes, si alguno estaba ya rescatado, si tenían padres que podrían buenamente rescatarlos, cómo se llamaban los padres, de dónde eran, qué bienes tenían y todo lo demás. El resultado de la información debían entregarlo en pública forma a Orive para que éste se lo entregase a los señores del Consejo. ${ }^{30}$

Ahora bien, todos estos que reclamaban ayudas para rescatarse eran andaluces, no vasallos de la Orden, y ésta tenía como prioritario favorecer a sus hombres, de ahí que no es extraño que poco después de plantearse la concesión de la limosna a Orive y sus compañeros el Consejo encomendase a los gobernadores de la provincia de León y de los partidos de la Mancha y Ribera de Tajo y del Campo de Montiel y las Sierras (ambos partidos conformaban la provincia de Castilla) que se informasen de los vecinos y naturales de tierras de la Orden que estaban cautivos en tierra de moros, con expresión de nombre, sexo, edad, vecindad, calidad de sus personas, tiempo y lugar de cautiverio, nombre del propietario, bienes poseídos, valor de los mismos, rescates concertados, modos de pago y cantidades ya adelantadas. ${ }^{31}$ Parece que la declarada voluntad del Consejo era rescatar a todos los posibles peticionarios, pero sin postergar a sus vasallos.

Así se aprecia en la rendición de cuentas hecha por el freile Francisco Díaz de los 50.000 mrs. anuales que durante el período 1523-1525 había apartado para la finalidad de redimir cautivos, entre las rentas de los Hospitales de

30 Comisión informativa de primero de febrero de 1526 (AHT, leg. 78.110). Transcrita en Apéndice (doc. 2).

Se conserva la información, tramitada por Juan de Chinchón, a quien Orive otorgó poder en Gibraltar en 29/05/1526: éste recurrió al juez de residencia del Puerto de Santa María, ante quien presentó cinco testigos: Simón Pérez portugués, Cristóbal Martínez, ambos hombres de mar, Inés Fernández, mujer de Antonio Fernández portugués, Beatriz Álvarez, viuda de Juan Martínez y madre de Melchor, y Antón Ruiz de Montalvo, todos vecinos del Puerto. De sus declaraciones se deduce que todos ellos iban en la caravela del citado Antonio Fernández portugués, como marineros, salvo Melchor, que como yerno del armador iba de maestre de la nave; fueron apresados el 20/06/1525 a 12 leguas de Xarcel o Sargel, sobre Vélez; estaban desperdigados entre Vélez de la Gomera, Tetuán y Xauen, y sólo de uno de ellos se sabía que estaba en poder de Muley Abrahem. Todos eran pobres, como sus padres, y no se podían rescatar por sí mismos, de hecho, el testigo Cristóbal Martínez había prestado a uno de los mareantes una manta y una camisa para el viaje, en tanto que Antón Ruiz de Montalvo les prestó pan y vino para aviarse, a cambio de que le transportaran algunas mercancías (AHT, leg. 25.661) Significativamente, repiten los declarantes: «que no save este testigo dónde les venga remedio para ser resgatados, syno de Dios y de las buenas gentes». La resolución anotada al final del expediente dice: Al relator: «que quando la Orden enbiare hazer la redención se avrá memoria desto. En Granada a .VIII. de junyo».

31 Comisión informativa de 28 de abril de 1526 (AHT, leg. 78.112). Transcrita en Apéndice (doc. 3). De inmediado se dio orden al mensajero que iba a la provincia de León de llevar a su gobernador, don Diego de Córdoba, estante en Segura de León, varias cartas, entre ellas, "otra provisión para saber los cativos que ay en tierra de moros, que sean vezinos e naturales de la provincia de León»(AHT, leg. 78.113). A mayor abundamiento, en otra minuta de provisiones y memorias del secretario Guerrero: «provisiones a los governadores que, porque la Orden quiere faser redención, sepan sy ay cabtyvos e quiénes e dónde [son] vezinos e qué bienes tienen y enbíen al Consejo. Que Sancho de Paz ordene las cédulas para los administradores sobre los dineros que tiene de cabtyvos» (AHT, leg. 78.114).
Toledo y Talavera, que administraba. De los $150.000 \mathrm{mrs}$. destinados a ese fin Díaz había entregado, por cédula real de 20/05/1524, 30.000 mrs. a Miguel de Estrada, vecino de Úbeda, para el rescate de Bartolomé de Biedma y Francisco Dorador, vecinos de Bedmar, de las que ya nos hemos ocupado más arriba. A Antonio de Ahumada, vecino de Medina de Rioseco, por cédula de 25/08/1525, $9.600 \mathrm{mrs}$. para ayuda al rescate de Alonso de Ahumada. A Bartolomé Sánchez de Anguito, vecino de Torredonjimeno, por mandamiento del Consejo de 23/06/1526, otros 9.600 mrs. para ayuda al rescate de su hijo, Juan de Anguito. Así pues, de estos cuatro agraciados con limosnas para su liberación, dos eran vasallos santiaguistas (los de Bedmar), uno calatravo (el toxiriano) y el otro foráneo.

También se le recibieron en cuenta al administrador de los hospitales 18 reales que el fiscal de la Orden, Antonio de Valderrábano, había gastado en la prosecución de un proceso ante los contadores mayores sobre los derechos de la seda comprada para invertirlos en el rescate de cautivos; por mandamiento del Consejo de 07/10/1525. En 1523 Pedro Hernández de Busto, caballero de la Orden, había dado por bien pagados 9.000 mrs. que el freile Gómez de Tévar, entonces administrador de los dos hospitales, había abonado, contra libramiento de los señores del Consejo, a Juan de Ribadeneira, vecino de Málaga, es de suponer que para el mismo noble fin que todos los anteriores. También fueron dadas por buenas otras pequeñas cantidades gastadas en cuestiones de trámite, resultando alcanzado el administrador en algo más de 90.000 mrs., que entregó al contador Sancho de Paz, librándosele carta de finiquito. ${ }^{32}$

En los meses finales de 1526 y en los primeros del año siguiente los desvelos del Consejo se centraron en la redención de dos cautivos ilustres, capturados en la rota del marqués de Mondéjar: don Jerónimo de la Cueva y Francisco Hernández el Zegrí. El primero de ellos era hijo de don Antonio de la Cueva, de posible procedencia ubetense, como los comendadores y, luego, señores de Bedmar, del mismo apellido. En un momento indeterminado el Consejo había ordenado al freile Francisco Díaz que abonase 100 ducados a don Antonio, contra el fondo destinado a ello en los hospitales toledanos, pero, al haber ya rendido cuentas, como se acaba de ver, se dirigió el mandamiento de pago al contador de Paz. ${ }^{33}$

Por su lado, el Zegrí era hijo de Gonzalo Fernández, noble granadino de pasado nazarí completamente integrado en la sociedad cristiana; el hermano mayor de Francisco era caballero de Santiago, lo que seguro que favoreció el interés que la Orden se tomó en su rescate. A partir del memorial presentado por su hijo Juan - recogido en el documento 6 del apéndice- sabemos que Francisco cayó prisionero en el desbarato del Peñón de Vélez de 1525, donde estuvo prisionero varios años, aunque no tantos como dice su hijo; allí el Rey moro se tomó a pecho convertirle al Islam por las

32 La carta de pago lleva fecha de 21 de febrero de 1527 (AHT, leg. 78.122). Transcrita en Apéndice (doc. 4).

33 Mandamiento de pago de 14 de noviembre (AHT, leg. 78.239; mal colocada). Ya aparece en una anotación del secretario del mes de agosto (AHT, leg. 78.116). Existe otra anotación en un borrador de minuta, con temas de pasar a consulta («Doña Ysabel de Quintanilla, lo del cautivo", sin fiat al margen), de la que no sabemos nada más (AHT, leg. 78.120). 
buenas y, luego, por las malas, sin éxito, siendo finalmente rescatado por impulso del Emperador. ${ }^{34}$ La primera mención que aparece en nuestros documentos sobre este personaje proceden de una minuta de septiembre de 1526, justo un año después de su caída en cautividad; en la misma se ordenaba que se cobrasen las mandas recibidas para su rescate, valoradas en $30.000 \mathrm{mrs} .^{35}$

Al parecer el encargado de reunir el dinero para su redención fue el tesorero general del Reino de Aragón, al menos, así consta en un borrador de carta de pago, procedente de mayo de 1527; en el mismo se dice:

Yo, Luis Sánchez, thesorero general de SS.MM. del Reyno de Aragón, otorgo y conozco que rescebí de vos, Francisco Guerrero, secretario del Consejo de las Órdenes, para ayuda al rescate de Francisco Fernández, hijo del Zegrí, que está cabtivo en poder de los moros de allende, enemigos de nuestra Santa Fe Católica, los dineros y escrituras siguientes: Primeramente, quinze mill mrs. y dozientas y quarenta y qu[atro mrs.].

Es una lástima que el borrador esté incompleto, sin embargo, sabemos quiénes fueron los que contribuyeron para reunir esa cantidad inicial, de acuerdo con el contenido de otro borrador, del mismo mes:

Lo que he recibido para ayuda al rescate del Zegrí es lo syguiente:

De Antonio de Valderrábano, caballero y fiscal de la Orden, 20 ducados que le dio el conde de Osorno, presidente del Consejo de Órdenes.

Del secretario Urrías, dos ducados.

De Pedro Hernández de Ludeña, freile de la Orden y capellán real, dos ducados que le dio don Íñigo Manrique, corregidor de Granada.

Del dicho Ludeña, dos ducados que le dio don Rodrigo Manrique.

Del dicho Ludeña, dos ducados que le dio el comendador Barradas.

Del mismo, un ducado que le dio Jaime de Marcilla.

Del mismo, 10 ducados viejos, que el dio el secretario Cobos, faltos de 13 gramos (3.685 mrs.).

Del mismo, un castellano que le dio Pedro Ruiz de La Mota, falto de un gramo (480 mrs.).

Del mismo, seis reales que le dio el secretario Zuazola. En total, 15.244 mrs. $^{36}$

Nada más dicen los documentos santiaguistas sobre el Zegrí; ahora bien, su tiempo de cautiverio en Vélez no queda claro, pues, a tenor de nuestros documentos, se siguió gestionando el asunto durante, al menos, más de año y medio.

34 Algunas indicaciones sobre este linaje en el trabajo de Enrique Soria Mesa (1992). Sobre el padre de nuestro personaje, véase García Pedraza 1995. Agradezco las indicaciones bibliográficas sobre esta familia recibidas de Enrique Soria, con su habitual amabilidad y competencia; también ha llamado mi atención sobre la existencia de memorial recogido en Apéndice (doc. 6).

Se llegaron a pedir por su rescate mil ducados (López de Coca 1993: 222). Por su parte, Amalia García nos aclara que anduvo prisionero en Vélez 15 meses y que se pagaron por su liberación 1.800 ducados, además de un moro que tenía el Rey de Portugal (García Pedraza 1995: 42).

35 AHT, leg. 78.117.

36 AHT, leg. 78.125
Entre tanto, a las oficinas del Consejo no dejaban de llegar peticiones de ayuda económica para rescatar cautivos; así, en los inicios de 1528 el secretario del Consejo presentó una minuta con las siguientes solicitudes:

Memoria de los cabtivos que piden limosna para ayuda a su rescate:

- Juan de Bolaños, que dize que es natural de la Orden de Alcántara. ${ }^{37}$

- Ginesa Hernández, vezina de Málaga, por Alonso Pérez, su hijo.

- Catalina García, vezina de Uelva, por un su fijo.

- Andrés de Valdeyglesias, vezino de Málaga, por sí e por un su yerno.

- Antonio de Trillo, dize que dexó rehenes, como paresce por un testimonio. ${ }^{38}$

No es por ello extraño, ante la avalancha de peticiones, que la Orden procurase contar con todas las aportaciones de sus hospitales: ya se ha visto cómo los de Toledo y Talavera aportaban anualmente para ese loable fin 50.000 mrs.; pues bien, los de Cuenca y Alarcón, también pertenecientes al instituto santiaguista, destinaban cada año 30.000 para el mismo destino. En junio de 1528 se le ordenó al contador Sancho de Paz recibir de manos de Gregorio Suárez, enviado desde Cuenca por Diego de Torremocha, administrador de esos dos hospitales, la cantidad correspondiente al bienio 1526-1527, que los ospitales son obligados a pagar para redención de cabtivos; se le ordenaba tenerlos en depósito para abonarlos en lo que se le ordenase, aunque detrayendo 816 mrs. para los portes de traída de Cuenca. ${ }^{39}$

En años sucesivos ya sólo encontramos nuevas reclamaciones de pago a los hospitales y peticiones de distintos cautivos para que se les concediese alguna cantidad para su rescate.

En 1529 era María de Contreras, vecina de Sevilla, la que exponía

...que puede aver quatro años, poco más o menos, que los moros, enemigos de nuestra Santa Fe Católica, captivaron a Alonso Muñoz, su hijo, que diz que hera de hedad de onze años, e que en el dicho captiverio lo tiene el alcaide Delantete, en la çibdad de Fez, e que tiene concertado su rescate en cien ducados de oro, e que al tiempo que fallesció la muger de Francisco Oliberos, vecina de la Higuera, diz que mandó de sus bienes cinco mill mrs. de limosna para redención de captivos, e que al presente están depositados en poder de Andrés de la Huerta, su albacea, e que porque ella es pobre e no tiene de qué pagar el dicho rescate, que me suplicava mandase le fuesen dados los dichos cinco mill mrs. en limosna.

Se acordó dar comisión al gobernador de la provincia de León para comprobar si en dicha circunscripción había persona también acreedora a dicha limosna o con la que se tuviera mayor obligación, de no ser así, que le hiciera entregar a la peticionaria dicha cantidad. ${ }^{40}$

37 Un Juan de Bolaños, vecino de Marbella, consta en agosto de 1526, viajando en un bergantín a Vélez de la Gomera con 2.000 ducados y un cautivo moro para rescatar a Sancho de Biedma (López de Coca 1993: 227).

38 AHT, leg. 78.134.

39 Mandamiento de 17 de junio (AHT, leg. 78.138).

40 Comisión de 11 de agosto (AHT, leg. 78.152). La semana anterior se le había concedido licencia para pedir limosna para el rescate de su hijo, pastor, llevado a Vélez de la Gomera. 
Pasados cuatro meses, libraron provisión a Francisco Guerrero, secretario del Consejo de las Órdenes: por una cédula habían mandado al bachiller Alonso Hernández, administrador de los hospitales de la Orden en Cuenca y Alarcón, que enviase $81.000 \mathrm{mrs}$. que quedaban debiendo para la redención de cautivos de ciertos años pasados; el administrador los había enviado, estando el Consejo en Granada en 1526, con Rodrigo de Alcayra, al que retribuyeron con $1.147 \mathrm{mrs}$. de salario, dando el resto (79.853 mrs.) lo diese al secretario Guerrero.

Ahora Josarte Martín clérigo, natural de Arcaniz [Alcañices], en el obispado de Zamora, Juan Oliver, natural de la villa de Valladolid, Antón de Cazorla, natural de la villa de Cazorla, y Alonso Asturiano, natural de Coydero [Cudillero], en las Asturias de Oviedo, expusieron que, estando ellos cautivos de los moros de allende, fueron rescatados por Juan de Mendiluchaga, que pagó por Josarte 65 ducados, por Juan 60, por Antón 61 y por Alonso 40, total 226 ducados, comprometiéndose a devolvérselos pasado un tiempo después que estuviesen en España; eran pobres y no podían pagar el rescate. Suplicaban se les pagase dicha cantidad o la porción que tuviesen por bien, mandándolos pagar a Domingo de Busturia, en nombre de Mendiluchaga, a quien había traspasado la deuda. Realizada por el Consejo cierta información, acuerdan pagar a Busturia los 65 ducados de Josarte Martín clérigo y 80,5 ducados de la mitad de los rescates de Juan, Antón y Alonso, total 145,5 ducados, que montaban 54.562,5 mrs., ordenándole a Guerrero entregarlos a Busturia o a su apoderado, tomando carta de pago. ${ }^{41}$

La gestión del asunto por parte del secretario Guerrero continuó el año siguiente, así, se le dio orden de pago: de los 79.853 mrs. que, por mandado del Consejo, le había dado Rodrigo de Alcayra, «de los que con él enbió el bachiller Alonso Hernández, administrador de los Ospitales que la dicha Orden tiene en la cibdad de Cuenca e villa de Alarcón, para la redención de cabtivos, distes por mi mandado a Domingo de Busturia 54.562,5 mrs. para ayuda a pagar el rescate de ciertos cabtivos»; debía tener en depósito el resto, con un interés de $30 \mathrm{mrs}$. el millar, de modo que aún retiene 22.900 mrs. Ahora, Marina Valenciana, vecina de la Fuente del Maestre, le había expuesto que su marido, Alonso Hernández, llevaba cautivo 11 años en Argel y por ser pobres no lo podía rescatar. Le ordenaron pagar los mrs. restantes a la peticionaria, recibiendo de ella carta de pago, pasándole en cuenta y liquidándole lo debido por el depósito hecho en él. ${ }^{42}$

41 Mandamiento de pago de 10 de diciembre (AHT, leg. 78.156).

42 Provisión de 4 de abril de 1530 (AHT, leg. 78. 160).

Cabría cuestionarse si siempre se destinaron los fondos para redención de cautivos a ese caritativo fin; los documentos conservados nos dicen que no en todas las ocasiones, ya que, cuando el Consejo andaba corto de recursos, echaba mano de este depósito, como ocurrió repetidamente en noviembre de 1526 y, luego, en 1528: el 12 de noviembre de aquel año ordenaron al contador que abonase al capellán Ludeña, ya citado, 40 ducados del fondo de rescates para atender los gastos hechos por el obispo de Marruecos, conservador de la Orden, en sus traslados y en Granada, cantidad que aumentaron en 10 ducados más el día 16; ese mismo día, se le ordenó abonar contra el mismo depósito 31.875 mrs., a cuenta de los 54.375 mrs. del salario de 155 días, debido a Nuflo Maymón, caballero de la Orden, «que se ocupó en yr a Portugal e a otras partes destos Reynos a buscar e prender a don Luis
Simultáneamente, libraron otra orden de pago contra el contador Sancho de Paz para que abonase a Marina 3.350 mrs. «de qualesquier mrs. que ayáys recibido o recibierdes para redención de cabtivos»..43

A pesar de los dos prometedores abonos recibidos por la mujer, el asunto se dilató, al menos hasta finales del año siguiente, cuando se dio mandamiento de pago a Francisco Sayago, vecino de la Fuente del Maestre, a petición a Alonso Hernández: habían hecho limosna a Marina Valenciana de 70 ducados (26.250 mrs.) «para ayuda al rescate de Alonso Hernández, su marido, qu'estava cabtivo en poder de los moros de allende, enemigos de nuestra santa Fee Cathólica»; Sayago, con poder de Marina, había cobrado esa cantidad de manos del secretario Guerrero, según carta de pago presentada, obligándose por sí y por sus poderdantes Juan de Sayago de la Corredera y Francisco de Aguilar, vecinos de la villa, a emplearlos en dicho rescate, dentro de cierto plazo. Ahora Alonso se presentó ante el Consejo y expuso que Pedro Espina mercader, vecino de Valencia, «en confiança de la dicha limosna e de cierta obligación que diz que le hizo lo sacó del dicho cabtiverio e lo rescató por ciento e diez ducados, e que para en quenta de la paga dellos os pidió los dichos setenta ducados e no se los quesystes dar syn especial mandamiento myo o de los del dicho mi Consejo».

Dieron orden de abonárselos en 3 días; de lo contrario que el gobernador de la provincia, su teniente o los alcaldes ordinarios de la villa ejecutasen sus bienes hasta tanto que el cautivo fuera pagado de la limosna y de las costas y gastos hechos. ${ }^{44}$

La siguiente noticia se demora hasta 1533 cuando se dictó nuevo abono en el contador de Paz a favor de Esteban Doria Grimaldo, mercader genovés, residente en la Corte, por valor de 1.000 ducados para rescatar cristianos de tierra de moros, con la condición de no gastar más de 70 ducados por persona, según Establecimiento de la Orden. ${ }^{45}$ Por esas

de la Cueva e a don Francisco de Tovar Ávalos, cavalleros de la dicha Orden», a razón de un ducado diario. Como no había otros fondos, habían decidido tomar prestadas todas esas cantidades del dinero de los rescates ( $\mathrm{AHT}$, leg. 78.239; mal colocada). Se refiere a la persecución que se practicó contra esos caballeros por haber sido testigos del desafío entre don Diego López Pacheco, comendador de Medina de las Torres, y frey Gutierre López de Padilla, comendador calatravo de las casas de Sevilla, el cual resultó muerto durante la lid por un desgraciado accidente; pasado un año, don Luis fue condenado en rebeldía a servir cuatro años «en la frontera contra los ynfieles, en la parte que por mí le fuese mandado", en 10 años de destierro de la Corte y cinco leguas alrededor y pérdida de sus bienes para la cámara real, tras la cual compareció en el convento de Uclés a purgar sus culpas (AHT, leg. 78.126). Se conserva numerosa documentación del suceso, incluida la lid medieval en que se enzarzaron ambos comendadores.

Para 1528 se volvieron a tomar prestados $10.000 \mathrm{mrs}$. del mismo fondo de rescates, por carecer de otros recursos, cuando hubo que pagarse al letrado y escribano que habían participado en el esclarecimiento de la muerte de Pedro Román, vecino de Ocaña, pues no se había podido determinar el obligado al pago de sus derechos y salarios (AHT, leg. 78.140).

43 AHT, leg. 78.140.

44 Provisión de 15 de diciembre de 1531 (AHT, leg. 78.180).

45 Mandamiento de pago de 3 de octubre (AHT, leg. 78.202). En efecto, estaba dispuesto que la Orden sólo ayudase en los rescates hasta ese máximo, salvo que el cautivo fuere caballero de la Orden o caballero seglar apresado luchando bajo la bandera de Santiago, en cuyo caso quedaba al arbitrio del maestre destinar al rescate lo que le pareciere (Medrano, G. de. 1627: tít. XIX, cap. VI). 
mismas fechas se aprecia la relajación de los administradores de los hospitales de Santiago a la hora de remitir a la Corte su contribución anual al fondo de rescates. ${ }^{46}$

Ya en 1535 se libra la última ayuda del período estudiado, mediante cédula de la Reina, de nuevo contra dicho contador: Mayor García, vecina de Villamayor de Santiago, expuso en el Capítulo general de la Orden celebrado en Madrid «que, yendo sobre mar, en nuestro servicio, Pedro de Moraleja, su hijo, puede aver cinco años, poco más o menos tienpo, lo cautivaron e tienen ciertos moros del Reyno de Fez, enemigos de nuestra Santa Fe Católica», faltándole por recaudar para el rescate 60 ducados, por lo que suplicaba que se le hiciese limosna de los mismos. Fue acordado en el Capítulo que el contador diese esa cantidad para el rescate del chico, de los fondos para redención de cautivos que administraba. ${ }^{47}$

La última referencia de interés se produce unos meses después; se trata de la cuenta de las andanzas del fraile mercedario Juan de Iribas por Italia y Túnez, con la finalidad de rescatar 42 cautivos. ${ }^{48}$

$$
* * *
$$

Como creo que ha quedado claro a lo largo de las páginas anteriores, uno de los principales focos de piratería y captación de cautivos que preocuparon a las autoridades españolas del momento fue Vélez de la Gomera, ciudad marítima marroquí situada casi en la vertical de la capital malagueña, a 100 millas náuticas de ésta; las actividades piráticas de los musulmanes de Vélez podían ser contenidas o limitadas por el control del Peñón ubicado junto a su costa, razón por la cual la conquista del mismo por el conde Pedro Navarro en 1508 supuso un respiro para la navegación hispánica por la zona, si bien la incuria de la administración favoreció que se desatendiese su defensa y recayese en manos del rey de Vélez en 1520. A partir de ahí se aprecia un recrudecimiento de las actividades de piratas berberiscos y turcos, que pululaban por el mar de Alborán, llegando incluso a pasar al Atlántico. Por ello no extraña que a la altura de 1525 las autoridades andaluzas armasen una poderosa flota para intentar retomar el Peñón.

En septiembre de ese año zarpó la flota de Málaga con 70 navíos, al mando del marqués de Mondéjar, con «la casi totalidad de las guarniciones del reino de Granada, dirigidas por los capitanes más veteranos y por lo más selecto de la pequeña nobleza granadina. Pero ni se consigue la sorpresa ni el artillero en cuestión cumple con lo prometido, de forma que las tropas echadas en tierra son masacradas por los moros y los contingentes que desembarcan en las

46 Recordatorios de 12 de junio al bachiller Juan Fernández de Balboa, administrador del hospital de Toledo, y al del hospital de Cuenca, sobre los 50.000 y 30.000 mrs., respectivamente, correspondientes al ejercicio anterior, aún no abonado (AHT, leg. 78.198).

47 Cédula sin fecha, pero datable en abril de 1535 (AHT, leg. 78.220).

48 Cuenta y finiquito de 18 de septiembre de 1535 (AHT, leg. 78.225). Transcrita en Apéndice (doc. 5), la gloso más adelante.

Se conserva un hermoso librito, incompleto, que recoge los expedientes personales de los 86 cautivos rescatados desde Ceuta por Juan de Herrera de Madrid, por cuenta del Consejo de Órdenes, en 1559. Me reservo, de momento, la signatura de esta joya de su género, que espero estudiar próximamente. asperezas del Peñón terminan siendo abandonados a su suerte. [...] el fracaso de esta expedición se debió tanto al fallo de la sorpresa como a la falta de reacción del marqués de Mondéjar, que ni siquiera intentó rescatar a los destacamentos que habían puesto el pie en el Peñón». ${ }^{49}$

Es evidente que los veleños estaban esperando el desembarco y el factor sorpresa se volvió contra los invasores andaluces; estoy en condiciones de aportar argumentos nuevos sobre las causas de esta derrota, sin duda, más importante de lo que las fuentes españolas de la época reflejan.

Para ello contamos con un precioso documento de la Chancillería de Granada, datable en torno a junio de $1537 . .^{50}$ En éste se pone el foco sobre Francisco de Guzmán, alguacil morisco de Frigiliana, en la costa malagueña, contra el que se dirigieron las acusaciones más atroces:

...sobre razón qu'el susodicho era acusado, diziendo qu'el susodicho aver avisado al Rey de Vélez de la Gomera que Nos enviávamos nuestra armada contra el Peñol e por averle avisado se avía dexado de tomar y avían muerto muchas presonas y otras cabtivado, y asy mesmo avía muerto a un criado suyo, cristiano viexo, y le avía desollado la cara por que no fuese conocido, y qu'el susodicho tenya conpañya con otros moros y andavan cativando y salteando cristianos, y asy mesmo que, yendo el dicho Francisco de Guzmán, vezino de la dicha villa, tenya en su casa una mazmorra, en que tenya metidos y presos los dichos cristianos, y asy mesmo el susodicho tenya en su casa armas, asy ballestas como otras, más otros cargos no especificados.

Enjuiciado por los alcaldes del crimen de la Audiencia granadina, fallaron en vista y revista contra el acusado: le absolvieron de la instancia, seguramente por no poder probarse fehacientemente su responsabilidad, pero le impusieron la prohibición, bajo pena de muerte y pérdida de la totalidad de sus bienes, de acercarse a menos de 10 leguas de la costa, limitación que en revista se redujo a la mitad. ${ }^{51}$ Es evidente que tenían graves sospechas de su actividad y prefirieron curarse en salud, imponiéndole esa especie de medida cautelar, que le alejaba de su lugar de residencia y de sus medios de subsistencia, legales o no.

No habían pasado nueve años cuando el reo obtuvo cédula real que mitigaba la anterior medida, pues le permitía vivir en el lugar de Cómpeta, dentro del límite de las 5 leguas que tenía prohibido, sin que pudiese salir de allí. Se decía persona de 80 años y que sus hijos vivían en esa alquería. No deja de llamar la atención la misericordia regia con un súbdito desleal al que la justicia sospechaba responsable del tremendo desbarato de 1525.

49 Datos de la historia del Peñón (López de Coca 1993: 213-222); el relato del desbarato en la última de esas páginas. En ellas refiere que la iniciativa y la causa del fracaso fue la actuación de un artillero capturado por los moros, que se ofreció a favorecer el desembarco.

50 ARChG, leg. 5.617. Falta el pliego final, donde constaba la fecha del documento; sin embargo, puede datarse en función de los otros documentos insertos. Se trata de un mandamiento a las justicias del Reino para que vean y cumplan las sentencias y cédula real incluidas.

51 Fallaron en vista los licenciados Diego Luzón y Alvaro Gil Mogollón y el doctor Alonso Méndez de Salazar (Granada, 22/01/1528) y en revista Mogollón y Salazar con el licenciado Alonso López Cerrato (Granada, 10/07/1528); en ambas instancias actuó de fiscal el doctor Ribera. 
El Rey. Por quanto por parte de vos, Francisco de Guzmán, vezino del alquería de Xátar, qu'es en la jurisdición de la cibdad de Alfanbra [por Alhama], nos fue fecha relación que el año pasado de myll e quinyentos e veynte e siete años fuiste acusado criminalmente ante los dichos alcaldes del crimen de la nuestra Audiencia e Chancillería que reside en la cibdad de Granada, por nuestro procurador fiscal de la dicha nuestra Audiencia, diziendo que avíades cometido muchos delitos, e como quyera que fuiste ausuelto de la ynstancia que os opusyeron, por algunas cabsas que les movieron, os desterraron perpetuamente de la costa de la mar del nuestro Reyno de Granada, con cinco leguas alderredor, como lo podíamos mandar por una carta exsecutoria que contra vos por lo susodicho mandamos dar de los nuestros alcaldes [qu]e ante algunos de los del nuestro Consejo presentaste e que guardando lo en ella contenido después acá, a casy diez años, avéys andado fuera de las cinco leguas de la costa, donde avéys padescido e padescéys mucho trabaxo e fatiga, por ser como soys muy viejo, de hedad de más de ochenta años, e no tener con qué sustentar, porque vuestros fijos e parientes de quyen podíades ser alimentado biben en los lugares comarcanos de la mar, dentro de las dichas cinco leguas, suplicándonos e pidiéndonos por merced que porque no peresciésedes de fanbre, fuésemos servidos solamente de alçar el dicho destierro de la dicha alquería de Cónpeta, donde biben vuestros fijos, que está a tres leguas de la dicha nuestra costa, e como la nuestra merced fuese.

Por ende, si ansy es, como en vuestra relación se contiene, que no ay parte querellosa contra vos por lo susodicho, usando con vos de clemencia e piedad, por la presente doy licencia e facultad a vos el dicho Francisco de Guzmán para que podáys entrar e estar e andar solamente el dicho lugar de Cónpeta e en su término e jurisdición, libremente, sin que por ello caygáys ny yncurráys en pena ny calunya de las contenidas en la dicha carta exsecutoria e sentencia de los dichos alcaldes del crimen que en ella va yncorporado, que para en quanto a esto solamente yo dispenso en todo ello, quedando en su fuerça y vigor, guardando en todo lo demás lo contenido en la dicha sentencia e carta executoria, e por esta nuestra carta mandamos a los del nuestro Consejo, presydente e oydores de la nuestra Abdiencia, alcaldes, alguaziles de la nuestra Casa, Corte e Chancillerías e a todos los corregidores, asystentes, governadores, alcaldes, alguaziles, merinos, prevostes e otras justicias e juezes qualesquier de todas las cibdades, villas e lugares de los nuestros Reynos e señoríos que vos guarden e cunplan e fagan guardar e conplir esta nuestra cédula e lo en ella contenido e contra ella no vos vayan ny pasen ny consientan yr ny pasar, por alguna manera, so pena de la nuestra merced e de diez mill mrs. a cada uno que lo contrario fiziere. Fecha en Valladolid, a diez e nueve días del mes de henero de myll e quinyentos e treynta a siete años. Yo el Rey. Por mandado de S.M. Juan Vazques.

A través de algunas provisiones de la misma Chancillería y de varios asientos de los protocolos granadinos es posible añadir algunos datos sobre el rescate de los cristianos apresados en Vélez de la Gomera por aquellos años, ampliando y completando, así, la información recopilada por López de Coca, González Arévalo y otros autores.

Mientras el Peñón estuvo en manos españolas se constituyó en lugar de tránsito de los cautivos que salían del Reino de Fez hacia Castilla, así, en 1518 tenemos testimonio de que Gonzalo de Parias, vasallo calatravo, volvía a dicho reino moro a través del Peñón para pagar su rescate al judío de Fez que le había permitido bajo palabra ir a la Península a conseguirlo, con seguro del sultán fecí. ${ }^{52}$ Pero, incluso en esos años (1508-1520), no se pudo impedir que en Vélez se siguieran manteniendo cautivos cristianos; es el caso del gienense Juan Ruiz del Bazo, quien en 1519 tenía dificultades para completar la totalidad de su rescate. ${ }^{53}$

Tras el fracaso de 1525 tenemos referencias de sujetos que habían intervenido en el desembarco y habían resultado cautivados o muertos. En esta última opción se situaba Gregorio López de Munuera, cuyo padre tenía en 1527 la ilusoria pretensión de recuperar los bienes del difunto, adquiridos por los veleños como botín de guerra. ${ }^{54}$ Sin embargo, el rescate del que contamos con mayor información es el del clérigo granadino, Pedro de Gámez. El 7 de abril de 1526 se celebró acuerdo entre Francisco de Mazuecos, contador del Patriarca de las Indias y canónigo de la catedral de Granada, y Juan Ramírez, vecino de esa ciudad, por un lado, y por otra el mercader granadino Francisco Fernández de Córdoba -al decir de López de Coca, viejo conocido del reyezuelo de Vélez ${ }^{55}$ - en los siguientes términos:

...dixeron quen ellos son concertados e convenidos en esta manera, que por quanto está catyvo en Vélez de la Gomera Pero de Games clérigo, e el dicho Francisco de Córdova va a le rescatar, por ende, el dicho Francisco de Córdova otorgó e se obligó de yr a la dicha cibdad de Vélez de la Gomera e rescatar el dicho Pero de Games clérigo e lo traer a esta cibdad de Granada a su costa e misyón, e que por razón dello los dichos contador Francisco de Maçuecos e Juan Ramires de mancomún e a boz de uno e cada uno dellos por sy por el todo, renunciando las leyes..., se obligaron a pagar al mercader o a su apoderado 150 ducados

52 Se trata de un seguro dirigido al alcaide del Peñón (Granada, 07/07/1518) (ARChG, leg. 5.529).

53 Incitativa al corregidor de Málaga o a su teniente: «... que él avía estado cabtivo en poder del Rey de Vélez de la Gomera e que en la redención que se avía fecho de cabtivos agora nuevamente saliera por rescate que eran ciento e veynte e cinco onças de plata e las cient onças, que son cada una trezientos e veynte mrs., e que avía pagado por él el provincial de la Santísima Trinidad de estos Reynos juntamente con otras limosnas que avía fecho en la dicha redención e que sabríamos que Juana Ruyz, su muger, buscara prestadas otras cinquenta onças de plata, las quales montavan quynze mill mrs., e por mandado del dicho provincial se dieran a Gaspar de Santistevan, vezino desa dicha cibdad de Málaga, para el dicho rescate, el qual dicho Gaspar avía dado e pagado las veynte e cinco onças, a cunplimiento del dicho rescate, segund parescía por un conoscimiento firmado de su nonbre, de que fazía presentación, e que se avía quedado con las otras veynte e cinco, el qual no gelas avía dado ni pagado, e que nos pedía e suplicava que porqu'él era pobre e salía de cabtibo e devía las dichas cinquenta honças de plata, e, sy non las pedía en limosna entre las buenas gentes, no thenía de qué las pagar». Solicitaba se librase provisión para que se apremiase al pago al depositario, sin contienda de juicio, «pues que era para su rescate, en que no se çufría dilación, porque pagava quatro ducados cada año en tanto que pagava el dicho rescate» (ARChG, leg. 5.531).

54 1527/09/14. Granada. Bartolomé Sánchez de Munuera zapatero, vecino de Granada, otorga poder a Juan Ruiz de Munuera y a Pedro Fernández de Munuera, ausentes, para cobrar cualesquier dineros, ropas, joyas y demás bienes dejados a su muerte por Gregorio López de Munuera, su hijo, "que fue muerto en el Peñón», que a él pertenecían como su legítimo heredero (Archivo Histórico de Protocolos de Granada [en adelante, AHPG], Granada-26, fol. 584r-585r).

55 López de Coca 1993: 223. 
de oro, qu'es el precio en qu'el dicho Pero de Games está rescatado, de los cuales le adelantaron en el acto 80 ducados (30.000 mrs.), de los que Córdoba se dio por contento; los restantes 70 ducados se los abonarían en plazo de 30 días tras la vuelta del cautivo a Granada, a razón de 450 mrs. cada ducado. Si rescatado el cautivo muriese, seguirían quedando obligados a pagale los 70 ducados restantes. Además, le abonarían las costas, que traxese por fe de otros catyvos que sean en Veles de la Gomera, qu'es menester hasta lo traer a esta cibdad de Granada.

El mercader se obliga a traer a Granada al clérigo cautivo, "e sy no lo traxere, syendo bivo, o trayendo fe cómo el Rey de Veles no lo quiere dar», devolverá los 80 ducados adelantados. ${ }^{56}$

El buen fin de la gestión del mercader granadino -converso de judío, con bastante seguridad, lo que explicaría, además, sus excelentes relaciones con los hebreos del séquito del régulo veleño- se demoró 15 meses, pues el 7 de agosto de 1527 otorgó la correspondiente carta de pago a Mazuecos y Ramírez; la forma de abono del dinero adeudado al mercader nos indica, por si hubiera alguna duda al respecto, de la íntima relación entre el comercio en general y los rescates de cautivos; decía Fernández de Córdoba en su finiquito:

...digo que por quanto yo me concerté con el señor contador Francisco de Maçuecos, canónigo de la Santa Yglesia de Granada, qu'es absente, e con vos Juan Ramírez, vezino desta dicha cibdad, qu'estáys presente, de rescatar a Pero de Gámez clérigo, qu'estava catyvo en Vélez de la Gomera, e por el dicho rescate os obligastes a me pagar ciento e cinquenta ducados de oro, de los quales me pagastes luego ochenta ducados e los mrs. restantes os obligastes a me pagar a cierto término, según más largo se contiene en la escritura que sobrello hezimos ante Gonçalo Quyxada, escrivano público desta carta a la qual me refiero; e agora vos, el dicho Juan Ramírez, me avéys acabado de pagar los dichos ciento e cinquenta ducados por que así me concerté, los quales yo he recebido en esta manera: ochenta ducados de oro al tienpo que se hizo la dicha contratación e asyento, e más que vos, el dicho Juan Ramírez, pagastes por mí a Francisco Gómez e a Diego de Soria, su yerno, veynte mill e ciento e treynta e quatro mrs. de cierta mercaduría que dellos conpré, por los quales mrs. hize una obligación a vos, el dicho Juan Ramírez, para os lo pagar a cierto plazo, la qual pasó ante Fernando de Figueroa, escrivano público desta dicha cibdad, la qual dicha obligación yo recebé en quantía de la dicha debda, e así mismo pagastes por mí a los dichos Diego de Soria e Francisco Gómez otros myll e seyscientos e treynta e siete mrs. a Francisco Ortyz, jurado e vezino desta cibdad, en

56 AHPG, Granada-23, fol. 187r-188r. El día anterior Juan Vizcaíno, escudero en la Alhambra, hijo de Juan Vizcaíno, vecino de Granada, en la collación de San Andrés, se había obligado a pagar al señor Francisco de Mazuecos y a Juan Ramírez, ausentes, 30 ducados de oro (11.250 mrs.), «por razón que yo los salgo a pagar de llano en llano para ayuda al rescate de Pedro de Games clérigo, qu'está cativo en allende y vosotros los salistes a dar e pagar por mí a Francisco de Córdova mercader, vezino desta cibdad, que va a sacar el dicho cativo y le fezistes obligación por ellos, y yo los salgo a pagar, faziendo de debda agena mía propia», a abonar sin contienda de juicio en plazo de 15 días tras el retorno de Gámez a la ciudad, «y sy antes fuere muerto, que trayendo testimonio de cómo fue rescatado» (Ibidem, fol. 178v-179v). El documento no expresa la relación de parentesco u otra entre Vizcaíno y Gámez. mi nonbre e con mi poder que yo le otorgué, honze myll e quinientos e diez e ocho mrs., e los otros mrs. restantes, a conplimiento a los dichos ciento e cinquenta ducados, asy en dineros contados, realmente e con efeto, e más me distes e pagastes treynta e dos honças e media de plata, que son de derechos que vos, el dicho Juan Ramírez de Córdova, hezistes en el rescate del dicho Pero de Gámez, todo lo qual me distes e pagastes en dineros contados, realmente e con efeto, de que me otorgo e tengo por contento e pagado. ${ }^{57}$

No había transcurrido un mes del rescate del clérigo cuando ya el rescatador profesional que era Fernández de Córdoba contraía una nueva obligación, la de ir a rescatar de nuevo a Vélez de la Gomera a Sebastián Román, vecino de Granada, en unos términos parecidos al anterior:

Francisco Fernández de Córdoba mercader, vecino de Granada, en la collación de Santa María, de un lado, y de otra Alonso de Villarreal, también vecino, dixeron que ellos son concertados e convenydos que por quanto está catyvo en Vélez de la Gomera Sebastián Román, e el dicho Francisco de Córdova, a ruego del dicho Alonso de Villarreal, va a lo rescatar, por ello Francisco se obligó a ir a dicha ciudad y a rescatarlo, trayéndolo a Granada a su costa, e que por razón del dicho rescate el dicho Francisco de Córdova se obligó de pagar al amo del dicho esclavo cien ducados de oro, qu'es el precio en que el dicho Alonso de Villarreal dixo qu'está rescatado; de esa cantidad recibió el mercader adelantados de Catalina Fernández de Valenzuela, madre de Sebastián, 50 ducados, que recibió en Bartolomé Ramírez mercader, dándose de ellos Francisco por pagado. Los otros 50 ducados se obligó a abonárselos Alonso de Villarreal en un plazo de 4 meses tras el retorno a Granada del cautivo, a razón de 450 mrs. el ducado, trayendo testimonio de cómo fue rescatado, pues si el cautivo muriese después o sucediere otro caso fortuito, Villarreal siga quedando obligado al pago concertado, demás de todos los susodichos mrs. de costas e otros derechos que traxere por fee del dicho Sebastián Román o de catyvos qu'están en Vélez, [qu'es] menester de costas e derechos fasta lo traer a esta cibdad de Granada, e el dicho Francisco Fernandes de Córdova, como principal, e Juan Pérez, su hijo, qu'estava presente, como su fiador e principal pagador, e anbos a dos de mancomún e a boz de uno... e, sy no lo traxere, syendo bivo o trayendo fee cómo su amo no lo quyere dar, que devuelvan a Catalina el dinero adelantado, ambos de mancomún. E sy pareciere por ynformación qu'el dicho Francisco de Córdova fuere muerto, que les puedan executar a ellos o qual dellos por los dichos cinquenta ducados, con más las costas. ${ }^{58}$

En el mismo acto y día los hermanos del cautivo se obligaron solidariamente al pago al mercader, cubriendo, así, las espaldas a Villarreal:

Alonso Román, Bartolomé Sánchez Román, Pedro de Valenzuela, tejedor de terciopelo, y Francisco Román, hermanos y vecinos de Granada, dezimos que por quanto vos, Alonso de Villarreal, vezino desta cibdad de Granada, a nuestro ruego vos obligastes de pagar a Francisco de Córdova, vezino desta cibdad, por el rescate de Sabastián Román, nuestro hermano, que va a lo rescatar a Bélez de la Gomera, cinquenta ducados de oro e justo peso, a razón de

\footnotetext{
57 AHPG, Granada-26, fol. 491r-492r.

58 Acuerdo de dos de septiembre de 1527 (Ibidem, fol. 536r-537r).
} 
quatrocientos e cinquenta mrs. cada ducado, e más todas las costas e derechos que hiziere fasta lo traer a esta cibdad de Granada, todo lo qual os obligastes de le pagar dentro de quatro meses después qu'el dicho Sebastián Román fuere venydo a esta cibdad de Granada, segund más largo se contiene en la obligación que oy, día de la fecha desta carta, e ant'el escrivano público desta carta le hezistes, por ello los cuatro hermanos se obligan a pagar a Villarreal los ducados adelantados, con las costas y derechos causados, de acuerdo con la fe de catyvos o de otras personas que Francisco Fernández les presentase, dentro del plazo de los 4 meses tras el retorno del cautivo a la ciudad. ${ }^{59}$

Pasados algunos años, contamos con el testimonio de Diego de Buytrago, cautivo en Vélez, que reclamaba el pago de deudas a favor de su padre y de sí mismo a fin de redondear su rescate. ${ }^{60}$

Pero, como digo, rescates y comercio ordinario andaban estrechamente entrelazados, como se ve en las actividades del mercader Fernández de Córdoba; así, se adivina detrás del poder concedido por el jurado granadino Francisco Ortiz a su sobrino Luis de Silva:

...digo que, por quanto yo enbío con vos Luys de Sylva, my sobrino, e en vuestra compañía a Francisco de Córdova mercader, vezino desta cibdad, con hasta myll ducados de mercaduría, en camisas e ropas moriscas e otras joyas e en ciertos paños e saltynos e otras cosas, a contratar las dichas mercadurías a Bélez de la Gomera, todo lo qual va en seys arcas e en ciertos fardos, lo qual vos di e entregué a vos el dicho Luys de Sylva, por un memorial, firmado de mi nonbre, e por ciertas causas que para ello ay otorgo e conozco que doy e otorgo todo my poder conplido bastante a vos el dicho Luys de Sylva, my sobrino, para llevar esas mercancías como factor suyo, negociándolas con consejo de Francisco de Córdoba. ${ }^{61}$

Dichas contrataciones, aunque no se exprese con claridad, tienen como trasfondo la realización de rescates, habida cuenta de la prohibición de exportar moneda a Berbería; así se vuelve a adivinar en el poder concedido por Diego de Ayala, mercader burgalés, vecino de Lisboa:

...digo que por quanto yo tengo hecha cierta contratación con mosén Capaz judío,62 criado del Rey de Bélez

59 Ibidem, fol. 537r-538r.

60 1533/10/01. Granada. Citación por nueva demanda a Beatriz de Salazar, viuda y heredera del contador Diego de Buytrago, a petición de Luis de Arenas, procurador de Diego de Buytrago, cautivo en Vélez de la Gomera, que expuso que «Pedro de Buytrago, padre de su parte, avía servido una lança nuestra, como escudero en la cibdad de Vera doze años y más tienpo, que ganava en cada un año diez e ocho myll mrs., lo qual el dicho vuestro marido, como hermano del padre de su parte y contador de la dicha capitanya, los avía recebido y cobrado e se los avía llevado, y que su parte avía servido al dicho Diego de Buytrago dos años de muy buen servicio, en que avía merecido en cada un año seys myll mrs. e más, y que, así mismo, antes qu'el dicho contador Diego de Buytrago muriese, avía fecho su testamento, debaxo del qual avía muerto, por el que le avía mandado a su parte quarenta ducados para ayuda a su rescate, todo lo qual, como heredera del dicho Diego de Buytrago, vuestro marido, hérades obligada a pagar a su parte», sin quererlo abonar sin contienda de juicio. Es emplazada en 15 días (ARChG, leg. 5.586).

61 1526/04/25. Granada (AHPG, Granada-23, fol. 216r-216v).

62 Este judío aparece citado como mosén Rapez (por López de Coca 1993: 229), pero en las dos ocasiones en que aparece en nuestros documentos la lectura es clara como "Capaz» o, como mucho, «Capez». de la Gomera, sobre razón de ciertas mercadurías qu'él me a de entregar e yo le entregar en cierta forma e manera, según más largo se contiene en la escritura de contratación que con él fize en la cibdad de Málaga ante un escrivano público della, en veynte día deste presente mes de hebrero, en qu'estamos, por ello otorga poder al señor Francisco de Torres, vecino de Málaga, para cobrar en su nombre las mercancías contenidas en dicha contrato y entregar las que él estaba obligado. ${ }^{63}$

Porque la otra cara de la moneda era la realización de contrabando, en cuya persecución se destacó el Lcdo. Vasco de Quiroga, el futuro Tata Quiroga, tan querido en México, que aparece citado en un documento del veinticuatro granadino Luis Núñez:

...digo que por quanto por mandado del señor licenciado Vasco de Quyroga, jués de comisyón de S.M., por ante Julián Rodrigues escrivano fue fecho cargo de Pedro de Vaena, vesino de la cibdad de Almería, diziendo que avía llevado a tierra de moros ciertas mercadurías e cosas vedadas e no vedadas syn las registrar en Orán e contra las leyes e premáticas destos Reynos, e sobresta razón dizen aver yncurrido el dicho Pedro de Vaena en ciertas penas; por ello, otorga poder a Pedro de la Fuente, vecino de Granada, estante en la ciudad de Almería, para tomar, en su nombre, en fiado de la fas la persona del dicho Pedro de Vaena, como carcelero comentariense, e recibir todos los bienes del dicho Pedro de Vaena, que le están secrestados. ${ }^{64}$

Sin embargo, el verdadero reverso de los rescates que venimos tratando es la situación de los musulmanes que o bien querían ingresar en la Cristiandad o bien querían retornar de su cautividad a sus hogares. Ambas posibilidades las tenemos documentadas, aunque en muy corto número.

El caso más sangrante de los retornos de musulmanes a Berbería es el de Alí y sus tres esposas, Zaide, Haxa y Fá[ti] ma, que habían estado cautivos en el Reino de Nápoles y, a su paso por Gibraltar, fueron tomados por su corregidor por salteadores y retenidos allá. A la Chancillería le costó conseguir que aquél le remitiera los cautivos rescatados a fin de fallar el asunto. ${ }^{65}$ En una situación semejante de indefensión se encontraban en muchas ocasiones aquellos

63 1527/02/23. Granada (AHPG, Granada-26, fol. 126r-126v). Luis Frates y Pedro de Jaén, vecinos de Lisboa y Granada, respectivamente, testificaron «e saben que asy es su propio nonbre e qu'es mercader e vezino de Lisboa».

64 30/01/1527 (Ibidem, fol. 74r-75r). López de Coca, en el citado trabajo, menciona en varias ocasiones actuaciones de este licenciado.

65 1538/03/07. Granada. Sobrecarta al corregidor de Gibraltar o a su teniente, insertando provisión anterior: Gastón de Caicedo, procurador de Alí y Zaide, Haxa y Fá[ti]ma, sus mujeres, moros, expuso ante la Audiencia "que los dichos sus partes abyan estado cabtyvos en el Reyno de Nápoles e se abyan rescatado e sacado sus cartas del dicho rescate en forma y porque para yr a su tyerra su camino era la vya de Cádiz e de allí se abyan d'enbarcar con licencia del alhaqueque mayor de Castilla o su teniente e pagarle sus derechos, y que, estando sus partes en poder del teniente de alhaqueque de la cibdad de Gibraltar, vos los avyades presos y queryades tomar por cabtyvos, diziendo que eran moros y bynyan a saltear, vynyendo rescatados y con españoles y su byaje derecho para su naturaleza, e bos, sin enbargo de aber visto las cartas de rescate y lo demás que trayan para su libertad, los teníades presos», sin quererlos soltar, según testimonio presentado por Hernandarias de Saavedra, alhaqueque mayor de Castilla. Solicitaban que se les dejase continuar libremente su viaje con el alhaqueque o, al menos, se trajese la causa ante la Chancillería. 
musulmanes que deseaban tornarse cristianos, debiendo para ello forzosamente cambiar de residencia a un país de esa religión; así intentó hacerlo Catalina Morena, procedente de la ciudad de Tlemecén, que fue cautivada poco antes de entrar en Orán; sin embargo, la Audiencia granadina acabó por reconocerla como mujer libre, cristiana y malagueña. ${ }^{66}$

Orden de remitir a los moros ante la Audiencia en 15 días, a costa de los mismos, quedando presos en la cárcel real (Granada, 07/02/1538).

Alhaqueque y moros expusieron que el corregidor no había querido cumplir la provisión anterior, escudándose en cédula de la Emperatriz, que había ordenado se hiciese información del caso y se le enviase para que ella proveyese; lo que había alegado al efecto de quedarse con los moros, sin que hubiese causa para que la Audiencia no entendiese en el caso. Se le ordena cumplir la primera provisión, añadiendo 50.000 mrs. más a los 100.000 mrs. ya dispuestos en aquélla, apercibiéndole de que, de no cumplirla, se enviaría ejecutor a hacerla efectiva a su costa (ARChG, leg. 5.627).

66 1538/03/18. Granada. Ejecutoria a petición de Catalina Morena, estante en la ciudad de Málaga, contra Francisco Ortiz, su amo, vecino de dicha ciudad: a la justicia de la ciudad de Málaga y demás del Reino; se había tratado pleito ante el bachiller Rodrigáñez, alcalde mayor de Málaga, y luego ante el Lcdo. Molina, su sucesor, que llegó ante el presidente y oidores de la Audiencia por apelación, «sobre razón que la dicha Catalina Morena, a veynte e un días del mes de setienbre del año pasado de mill e quinientos e treynta e seys años paresció ant'el dicho bachiller Rodrigañes, alcalde mayor, y presentó ant'él un escrito e demanda en que dixo que, estando la dicha su parte en la cibdad de Tremecén, qu'es en las partes de África, tierra de moros, e syendo ynfiel e mora, alunbrada por el Espíritu Santo, con deliberación e voluntad determinada de se tornar christiana y venirse a la unión de la Santa Fee Católica, con deseo de participar de los sacramentos de la Santa Madre Yglesia e recebir agua de bautismo, se avía salido de la dicha cibdad de tierra de moros para se venir a Orán, tierra de christianos, y antes que llegase, estando en la Fuente, cerca de las huertas y muy cerca de Orán, ella y una mora que trayga consygo, las avía tomado y llevado un escudero a la dicha cibdad de Orán, e syendo libre la avía tomado e robado la libertad, que de derecho les pertenescía, y por fuerça y contra su voluntad la avía despojado della, haziéndola cativa y la avía dado a Pedro de Godoy y agora avía venido a poder del dicho Francisco Ortiz, vezino de la dicha cibdad, y so color de cativa la avía tenido e tenía por fuerça e contra su voluntad». Solicitaba que se la reconociese como persona libre y que su amo le restituyese su libertad y le pagase los servicios prestados del tiempo que la había tenido cautiva.

El alcalde ordena a Ortiz que en tanto durase la litispendencia no enajenase a la mora, tras presentar ésta una información de lo alegado, a instancias del juez. En la contestación a la demanda Ortiz pide que dirija la acción contra Antón de Logroño, que se la había vendido.

Sentencia: Catalina había probado que fue a Orán a tornarse cristiana, por lo que condenaba a Ortiz a dejarla en libertad, reservando su derecho a repetir contra los vendedores en saneamiento. Sin costas.

Ortiz apela, alegando que había sido cautivada por las gentes de armas de Orán y ganada de buena guerra; que cuando se tornó cris tiana ya era esclava; no se podía demostrar su voluntad de tornarse cristiana cuando fue capturada, por lo que había «de se estar a lo real y al hecho de que pudo constar e constava que hera mora e que avía sydo cautiva en justa guerra y en parte donde se solían hazer semejantes presas y calbagadas [sic] contra los enemigos e no créese que sy la dicha Catalina Morena tuviera libertad ella viniera a Orán a poder de christianos, que no fuera conservada en ella, pues allí estava nuestra justicia y capitán general de guerra y otros cavalleros cristianos, que no consyntieran que por nadie le fuera ocupada su libertad». Contesta Catalina que nada de lo dicho obstaba a lo establecido en la sentencia del alcalde mayor, pidiendo que su amo le permitiese acudir a defenderse ante la Audiencia, prestando fianzas.

Sentencia de vista: confirmatoria de la de primera instancia, sin costas (Granada, 12/02/1538).

Sentencia de revista: confirmatoria de la de vista, con costas (Granada, 28/02/1538).
Un caso parecido debió de plantearse poco antes sobre la libertad de Cristóbal de Orán, estante en Granada, contra Luis de Cárdenas, vecino de Córdoba. ${ }^{67}$ Finalmente, otra posibilidad de adaptación, cuando el cautivo se transformaba en cautivo de larga duración, es decir, en esclavo, era la manumisión, que sólo se producía por rescate o, más frecuentemente, por concesión graciosa del dueño, en agradecimiento por sus muchos años de servicios, como le ocurrió a Gómez Fernández, chico turco, capturado con cuatro años y liberado con $24 .{ }^{68}$ Se trata sólo de un ejemplo entre muchos otros. ${ }^{69}$

\section{Volviendo a los rescates protagonizados por la Orden de} Santiago, como ya se ha visto, contamos con dos rendiciones de cuentas, que relacionamos en Apéndice (documentos 1 y 5), donde se puede ver al detalle cómo se desarrollaban las redenciones de cautivos; en cierto modo, podría decirse que se trata de auténticos relatos, no en forma novelada, sino contable.

A petición de la parte vencedora, se libra ejecutoria, constando que las costas que Ortiz debería abonar a Catalina eran 126 mrs. Lcdo. Corral. Lcdo. Don Juan de Castilla. Lcdo. Melchor de León. Secretario, Gumiel. Sin derechos (ARChG, leg. 5.627).

Sería interesante saber el modo en que demostró la actora su intención; sospecho que el peso de sus convicciones y prácticas cristianas ante los clérigos malagueños debió de ser decisivo.

67 Se trata de una receptoria a las justicias de Málaga y Córdoba, de 19/05/1537, que no ofrece muchos más datos (ARChG, leg. 5.614).

68 1527/11/07. Granada. El comendador Gómez de Solís, veinticuatro y fiel ejecutor de la ciudad de Sevilla, «digo que por quanto yo tengo por my esclavo e cativo a vos, Gómez Fernandes, natural de Turquía, de hedad de veynte e quatro años, poco más o menos, e vos avéys estado en my poder dende que hérades de hedad de quatro años, por manera que me avéys servido veynte años, poco más o menos, e agora, de my propia voluntad e por servicio de Dios, nuestro Señor, e por el buen servicio que vos me avéys hecho todos los dichos veynte años, yo he por bien de vos ahorrar e libertar. Por ende, por esta presente carta vos otorgo e conosco que aforro e doy libertad a vos el dicho Gómez Hernández, mi esclavo, para que desde oy, día de la fecha desta carta, en adelante seays libre e horro e esento del dicho cativerio e servidunbre e como persona libre e horra del dicho cativerio e servidunbre vos podáys yr a bivir y estar a qualesquier partes e lugares donde vos quisierdes e por bien tovierdes, e podáys faser e hordenar vuestro testamento e dexar e mandar vuestros bienes a quyen quysyerdes e por bien tovierdes e faser todas las otras cosas e cada una dellas que persona libre e esenta del dicho cativerio e servidunbre puede e deve faser». Se obliga a tener esta manumisión por firme, so pena de 50.000 mrs., mitad para la cámara y mitad para el liberto. Obliga persona y bienes y renuncia leyes (AHPG, Granada-26, fol. 665v-666r).

69 Caso distinto es el de los berberiscos capturados en suelo español cuando saltaban a tierra para realizar sus periódicas razzias; se conserva un grueso proceso en el Archivo Histórico de Toledo, litigado entre el genovés Juan Agustín Pinelo, arrendatario de la encomienda del Valle de Ricote, poblada casi al completo por moriscos, y el Lcdo. Gaspar de la Fuente, alcalde mayor del partido de Caravaca, sobre la atribución de 10 berberiscos capturados con su arraez por vecinos de Mula y Ricote en noviembre de 1533, después de que saltaran de sus fustas en el Cabo de Gata; se acabaron perdiendo y sin víveres aparecieron en el Valle de Ricote, esperando tal vez encontrar abrigo entre sus antiguos correligionarios, los cuales tenían, sin embargo, una larga trayectoria de capturas de moros de los Reinos de Aragón o de Granada, que cruzaban descaminados entre los dos Reinos por tierras murcianas (AHT, leg. 4.271). Este proceso, en realidad, dos acumulados, es un pozo de datos sobre estas capturas, pues se trataba de averiguar a quién correspondían «las aventuras de moros», si a los captores o al comendador de la zona. 
Comenzando por el de 1525, cuyo destino fue la ciudad de Vélez de la Gomera, fue encomendado a Francisco Díaz, freile de la Orden, cura del Corral de Almaguer y, en esa época, administrador de los Hospitales santiaguistas de Toledo y Talavera, el cual comenzó su andadura en agosto de 1524, no finalizándola hasta fines de enero del año siguiente. Para realizar su labor redentora recibió, por cédula real, algo menos de 700.000 mrs. en metálico con cargo a las penitencias y otros recursos destinados a dicho fin; además, se le hizo cargo de algo menos de 200.000 mrs. por 32 paños que compró para usarlos en la redención (20 palmillas, dos leonados y diez morados), incluyendo más de $30.000 \mathrm{mrs} .{ }^{70}$ que obtuvo de ganancia al venderlos en Vélez (un $22 \%$ de beneficio). Así mismo, compró 577 libras y pico de seda en madeja -de las que se dañaron 16 a causa de los ratonespor valor de 407.000 mrs., que vendió en Vélez por 445.000 mrs. (un $11 \%$ de beneficio). ${ }^{71}$ Dada la prohibición de exportar moneda o metales preciosos, el modo habitual de salir al rescate era proveerse de mercancías valoradas en destino; una vez en tierra de moros, se vendían esos productos, que eran valuados en onzas de plata (320 mrs. por onza), dinero que se invertía en la compra de los cautivos. Por tanto, Díaz contaba para invertir en su viaje y en dicha compraventa con algo más de un millón trescientos mil mrs.

Así pues, desde el inicio del encargo el clérigo contaba tanto con una cantidad en metálico para los gastos del viaje y como remanente para usar en imprevistos o para invertir en el propio rescate, como con una serie de mercancías exportables con cuyo producto, una vez vendidas en destino, proceder a la adquisición del mayor número posible de cautivos.

A partir de ahí la data de la cuenta nos permite seguir los pasos del freile Díaz: hubo de marchar 45 días a la Corte para tomar nota del encargo del Rey de ir por cautivos a África; al parecer, venía de Cuenca, a donde escribió para que le remitiesen las cédulas necesarias para su pasaje; luego marchó a Llerena para recibir el dinero que se le había asignado -el contador Sancho de Paz era vecino de esa villa-, yendo escoltado por dos hombres; de ahí marchó a Granada y a Málaga, donde estuvo cuatro meses comprando la mencionada seda y esperando a ver si podía embarcarse para Vélez. En Málaga, a propósito de la adquisición de la seda, abonó distintas cantidades al jeliz y al çahoracador, ${ }^{72}$ además de lo pagado al corredor Rodrigo

\footnotetext{
70 Supongo que el precio de compra en Castilla engloba todos los demás conceptos (tinte, tundido, arpilleras, portes a Málaga y derechos del corredor), por lo que el beneficio anotado (31.945 mrs.) no se corresponde con el aritmético (42.590 mrs.). Se trata de una diferencia demasiado abultada para atribuirla a un error, errores que eran bastante comunes en estas cuentas. Tal vez se hayan descontado del beneficio final los conceptos arriba reseñados.

71 De nuevo hay error en este apunte y más grave, pues se dice que las libras de seda se compraron a 407.506 mrs. y se vendieron a $445.933,5$ (lo que hubiera supuesto un beneficio del 11\%), produciéndose un beneficio de 853.411 mrs.; a mi modo de ver, el escribano o freile Díaz alteraron el orden de la adición, pues sumaron los precios de compra y venta, para obtener el beneficio, resultando, así, una ganancia del $110 \%$. En cualquier caso, la cantidad que se admitió en el haber fueron los 445.933,5 mrs. De ser cierto ese notable beneficio el clérigo habría contado para su misión con un millón setecientos mil mrs. y pico.

${ }_{72}$ Así como la figura del jeliz es bien conocida, no puedo decir lo mismo del çahoracador o, tal vez, çahoraçador; la lectura del término es clara, y la mención parece indicar que era el que pesaba la seda.
}

de Jerez. Así mismo, hubo de remunerar los servicios del alguacil y de los porquerones que sacaron la seda de casa del jeliz y de la aduana de la seda para ponerla en poder de Rodrigo Álvarez. En ese tiempo andaba entre la capital malagueña y Granada, cumplimentando los asuntos que se le iban presentando: envió desde Málaga a Vélez de la Gomera y a Fez a Cristóbal de Jaén para conseguir seguros para su pasaje allá; despachó desde Granada un peón a la Corte para recoger diversas escrituras y saber si finalmente cruzaría hacia Vélez, pues había sabido que los trinitarios estaban operando allí en esos momentos; hizo saber a sus superiores "cómo se avían encarescido aliende los cabtyvos»; en Granada, finalmente, hubo de preocuparse en obtener provisiones de la Chancillería sobre los derechos a abonar a los arrendatarios de la seda, pues iba en detrimento de los rescates que les cobrasen derechos de salida por los productos que se exportaban para ello (recuérdese que el fiscal Valderrábano andaba litigando sobre ello ante los contadores mayores).

Cansado de la espera, fue a Burgos desde Málaga para dar cuenta de sus gestiones hasta la fecha, gastando en el viaje 35 días. Luego partió desde Toledo para Cuenca, donde adquirió los paños mencionados. A los 20 días que invirtió en ello hay que añadir otros trece, durante los cuales fue de la capital conquense a Málaga, acompañando a los recueros que transportaban los paños. Vuelto a la ciudad malacitana, aún permaneció en ella otros 68 días más hasta que finalmente embarcó para Vélez. Había acuciado a la Corte a que se tomase una resolución sobre su viaje, pues seda y paños se estaban deteriorando con la espera.

Antes de partir, sin embargo, había enviado un mozo a la Corte a dar cuenta de su salida -tal vez el mismo que le acompañaba habitualmente para su servicio personal-, y había pagado las obligaciones contraídas en el proceso que siguió ante el alcalde de la seda para sacar sus madejas, incluyendo a letrado, asesor de los jueces de la seda, escribanos públicos Juan Parado y Portillo, así como jueces y alguaciles que se ocuparon de levantar el depósito de la ropa y embarcarla. También debió de abonar 1.500 mrs. a Martín Sánchez, vecino de Málaga, porque hubo de despacharle a Vélez desde Málaga a fin de obtener un nuevo seguro,

porque quando llegó a Málaga halló que avía venydo allí un judío del Rey moro de Vélez a cobrar ciertos dineros que se devían al dicho Rey moro y que no lo dexaron yr a Sevilla ni a Granada, y temiento que por esto le hiziesen alguna represaria, enbyó por el dicho seguro.

No pagó flete, sino que compró el casco del navío en que cruzó a África, pagando por el mismo casi 9.000 mrs. El viaje de ida y vuelta se prolongó durante dos meses, durante los cuales mantuvo y pagó salario a un piloto, un arraez, tres marineros y un mozo de servicio de éstos.

Ya en Vélez de la Gomera rescató 45 cautivos, entre hombres, mujeres y niños, a diversos precios, con dinero propio y con cantidades que le abonaron los mismos cautivos y otras personas. De todo ello tomó testimonio ante dos escribanos locales, uno musulmán y el otro judío; vuelto a Málaga obtuvo otro testimonio notarial, concordante con el traído de Vélez. El régulo moro percibió de derechos el $8 \%$ del valor de las mercancías desembarcadas, el almojarife de la ciudad onza y media de plata por cada cautivo extraído, el almirante y alcaide de la mar, media onza por 
de cada redimido y el maestre Abrahán, escribano judío del reyezuelo, un tomín de plata por cautivo.

Para realizar su labor Díaz se acompañó de un intérprete, Gaspar de Santisteban, vecino de Málaga, el cual participó en el ajuste de los precios de los cautivos, en el peso de la seda y en hacer cuenta con los dueños de los liberados. Así mismo, sirvió junto al clérigo, desde principios de agosto, en Toledo, hasta fines de enero, en Madrid, un hombre encargado de supervisar los bienes exportados, así como la tripulación de la nao, en mar y en tierra. Además de pagar salario a un mozo de servicio, que fue a su lado, hubo de retribuir, así mismo, los servicios de mosén Capez judío, que fue a Barraos [¿Nador?] y a Melilla a traer dos cautivos, siendo retenido por el alcaide melillense allí durante 30 días. También pagó los honorarios de un cirujano en Vélez, que curó a un cautivo que se había cortado un dedo serrando.

De vuelta con los cautivos en Málaga, ${ }^{73}$ hubo de enviar a la Corte un mozo en relación con los problemas que había encontrado por causa de los derechos aduaneros, ${ }^{74}$ además, compró 4 bestias para llevar de Málaga a Toledo tres mujeres y un niño de los redimidos, junto con su hato; las mujeres, el niño y los hombres cojos fueron llevados de Toledo a Madrid, donde estaba la Corte, en dos carretas que hubo que adquirir. Naturalmente, tuvo que alimentar y sustentar a los 45 cautivos desde que salieron de Málaga hasta que llegaron a la Corte.

Para su entrada en la Corte compró una bandera, con su mástil, con las armas reales y la cruz de Santiago, así como hábitos para los cautivos y una cruz. Lástima que el documento no nos ilustre de la ceremonia de recepción de los cautivos por parte del Consejo. ${ }^{75}$

De la cuenta prestada resultó que Francisco Díaz había gastado $16.433,5 \mathrm{mrs}$. más de los que había recibido, por lo que el clérigo alcanzó a la redención en esa cantidad, pero se le descontaron otros gastos hechos en Vélez, sobrevalorados con respecto a los precios de Castilla, por lo que finalmente el alcance quedó reducido a $4.000 \mathrm{mrs}$. a favor el freile. Restaban para futuras redenciones las 16 libras de seda dañadas, que fueron dejadas en poder de Alonso de Montalbán, mercader de Toledo, así como el remanente dejado para atender los gastos aduaneros, para el caso de que no hubiera que abonarlos al final. ${ }^{76}$

73 Ya hemos visto más arriba cómo Domingo Izquierdo, vecino de Motril, uno de los rescatados, a pesar de haber jurado que iría a la Corte a presentarse ante el Rey, se le escapó al clérigo una vez vuelto a la Península; supongo que el testigo que depuso en el testimonio que presentó el freile sobre el caso, Diego Ramos, vecino de Almería, sería otro de los redimidos en aquella ocasión.

74 Había dejado depositados en Málaga, en manos del armador Gaspar de Santisteban, el intérprete, 63.580 mrs. para el caso de que hubiera que satisfacer los derechos de exportación de las mercancías llevadas a África.

75 Recordar, a este respecto, la recepción en Toledo de los cautivos cristianos liberados en Ronda, durante la Guerra de Granada, los cuales depositaron sus herrajes en las paredes exteriores de San Juan de los Reyes, donde todavía se conservan algunos de ellos.

76 Si hemos de hacer caso a lo dicho en el documento, el período justificado se extendió durante los meses de agosto de 1524 a enero de 1525, en el que transcurrieron 184 días, no obstante, si sumamos todos los tramos temporales mencionados en la cuenta, supuestamente consecutivos, el resultado es más del doble; caben dos explicaciones, o se solaparon hechos cuantificados en días o la rendición de cuentas incluyó error o engaño. Me inclino a pensar que el período de
Mucho más detallada resulta la cuenta rendida diez años más tarde por fray Juan de Iribas. ${ }^{77}$ Para desarrollar el encargo regio de ir a Túnez a rescatar cautivos recibió tres ingresos, que importaron un total de $362.550 \mathrm{mrs}$.: 20 ducados dados en mano por el Dr. Arcilla, difunto en el momento de la rendición de cuentas, más dos cédulas de cambio (letras de cambio) libradas por el mismo doctor en Juan Bautista Grimaldo, en Génova, y en Ortuño de Hecheaga, por el resto. El centro de sus operaciones para intentar llegar a Túnez sería, pues, Génova. ${ }^{78}$

Como era habitual, era preciso invertir la mayor parte de ese dinero en mercancías exportables a tierras musulmanas, productos valiosos para sus posibles compradores. Así, compró 300 docenas de bonetes berberiscos colorados, por algo más de 50.000 mrs.; 37 libras de oro hilado, por algo menos de 125.000 mrs.; 130 libras y media de corales, por algo menos de 50.000 mrs.; 10 piezas de paños florentinos, por algo más de 80.000 mrs.; 12 balas de papel de estraza, por 15.500 mrs., así como cordeles y cañamaza para atar y hacer balas los paños y un arca de dos llaves, donde preservar el oro hilado y los corales, por $1.000 \mathrm{mrs}$. Todo ello adquirido en Génova con la ayuda de Estéfano Bargadio Sauli, que evitó que el fraile fuera engañado. De todo ello hubo de pagar derechos del comercio y de exportación a Berbería (en total, 8,5\%), en cuyo pago intervino Grimaldo, reduciéndosele notablemente el abono final. Además de los correspondientes corretajes y el derecho de cencería, debido por la saca de mercancías de la capital ligur.

La primera intención de Iribas fue remitir esos productos a Livorno, para desde allí enviarlos a su destino final. ${ }^{79} \mathrm{De}$ hecho, pagó los fletes debidos, así como los salarios de los ganapanes que los transportaron al muelle de la marina desde la posada del fraile. Intervinieron, además, dos notarios, Jacobo Villamarín y Grigorio Espínola Picaluga, en sacar testimonio de las mercancías y en el poder otorgado a Grimaldo para actuar en su ausencia, respectivamente. Ya en Livorno, hubo de pagar los derechos de desembarco en la Casa de la Aduana, tras lo cual el mercedario partió para Populonia, desde donde escribió a Grimaldo para que le enviase cartas de recomendación para ser acogido en la nao que salía para Túnez. El útimo día de noviembre utilizó los servicios de una fragata para poner en Populonia las mercancías descargadas en Livorno, a fin de hacer el viaje a Túnez.

Finalmente, el viaje fue cancelado o, tal vez, no encontró pasaje en la nao, por lo que el fraile se vio obligado a desandar el camino realizado, devolviendo las mercancías a Livorno, vía Populonia, debiendo abonar de nuevo los derechos y los salarios de los arrumadores. Los productos

desempeño del freile fue mayor que el que recoge el documento y que distintas acciones se superpusieron.

77 Era comendador mercedario de la casa de San Nicasio mártir, cedida a esa orden por el cabildo de la iglesia colegial de Tudela en 1504; fueron sus predecesores en el cargo fray Alonso de Tarazona y fray Pedro de Lesaca (Díaz Bravo, fray José Vicente. 1956. Memorias históricas de Tudela: 388 Pamplona).

78 De hecho, la cuenta se rinde en moneda genovesa (libras, sueldos y dineros), traducidas a ducados y maravedíes, pudiendo haber en el cambio ganancia o no.

79 Salvo los bonetes, que fueron expedidos desde Savona a Génova, los demás productos salieron directamente desde Génova para Livorno. Curiosamente, cuando el fraile se refiere a este trayecto no habla del pago del flete, sino del «nolito», catalanismo (nolit). 
quedaron allá, en tanto el mercedario volvía a Génova a buscar nuevamente el modo de ir a Túnez; más tarde recuperó toda la mercancía, que fue llevada a su base genovesa en un alaúd y dos fragatas.

Por fin, encontró pasaje para ir directamente a Túnez en el galeón de Génova, pagando derecho de cencería, flete y seguro (más de 50.000 mrs.)..$^{80}$ Llegado a su destino final, Iribas consiguió rescatar a 42 cautivos, por los que pagó flete desde allí a Nápoles a razón de dos escudos por cabeza, sin contar las limosnas que recibió para ello del Virrey y Consejo de Nápoles, además de algunos particulares de la ciudad. Algo más costoso resultó el pasaje del rescatador desde Túnez a Marçara (Mazara del Vallo, Sicilia). Algo parecido puede decirse de sus pasajes a Nápoles y a Barcelona. En la ciudad condal compró una jaca, sobre la cual marchó a la Corte a dar cuenta al Consejo de sus exitosas gestiones.

Había salido de la encomienda de Tudela en 11/06/1533, desde donde fue a Madrid por indicación del Dr. Arcilla, saliendo de allí el 24 del mismo mes. Llegaría a Túnez en $15 / 02 / 1534$, de modo que invirtió en su viaje de ida 8 meses y tres días; durante ese período se anotó gastos de su persona, de su mozo y de su cabalgadura. En la capital tunecina se demoró hasta 09/12/1534 (9 meses y 26 días). Llegó a Sicilia el día 11 -allí se encontró con la carestía del vino, pero no se anotó el sobreprecio porque no lo consumió, al estar a dieta-. De allí cruzó a Nápoles, donde se demoró tres meses y medio, sacando testimonio de lo acontecido; además el Virrey de Sicilia le retuvo y le envió de nuevo a Túnez a realizar una serie de gestiones en nombre del Rey - «aunque anduvo medio mendicando y pasó vida arto lagradra» ${ }^{81}$. Desde su salida definitiva de Nápoles hasta su llegada a la Corte, en Madrid, pasaron cuatro meses, en los que realizó el viaje por mar a Barcelona, de allí se acercó a su encomienda de Tudela, encargándose de asuntos propios y realizando recados encomendados por otros cautivos que quedaban en Túnez, para, finalmente, encaminarse a Madrid, a donde llegó en julio de 1535. Hay que decir en descargo del buen fraile que no cargó en la cuenta los gastos hechos mientras estuvo ocupado en temas de su interés personal.

En la cuenta provisional, pues, se le cargaron 467.804 mrs., quedando alcanzado en algo más de cien mil mrs.

Digo provisional porque se le tomó otra cuenta respecto a las mercancías vendidas en Túnez (incluyendo las ganancias obtenidas) y su inversión en la redención. En este caso la rendición de cargo y data se hace en moneda genovesa y tunecina (abdalia de oro, equivalente a 40 nazaros de plata; 34 nazaros equivalían a un escudo). Los beneficios obtenidos con la venta de las mercancías genovesas en Túnez fueron mucho mayores que las llevadas 10 años antes a Vélez de la Gomera, en especial, en lo que se refiere a los bonetes berberiscos y las balas de papel.

Si valuamos el escudo a 391 mrs., ${ }^{82}$ la relación de precios

80 De acuerdo con los apuntes introducidos en la cuenta en este punto se entiende que el fraile fue desde Tudela a Villafranca de Niza (Villefranche-sur-Mer) a lomos de una mula, que le había prestado el comendador de su orden en Sangüesa; allí se le murió el animal, realizando el resto del viaje por mar: Génova, Pisa y Livorno.

81 El término es de lectura clara; tal vez se trate de un navarrismo; entiendo que se refiere a que llevó una vida muy lacerada o desdichada.

82 Se obtiene ese valor a partir de los datos suministrados por el propio documento: un escudo equivalía a 68 sueldos y 72 sueldos a un ducado. de compra en Génova y venta en Túnez con el correspondiente porcentaje de beneficio, sería la siguiente:

$$
\begin{aligned}
& \text { - oro hilado: } 123.390 \mathrm{mrs} \text { / / } 217.005 \mathrm{mrs} \text { / / 75,5\% } \\
& \text { - paño florentino: } 83.360 \mathrm{mrs} \text { / / } 144.670 \mathrm{mrs} \text { / / 73,5\% } \\
& \text { - corales: } 48.480 \mathrm{mrs} \text { / } 75.555 \mathrm{mrs} \text { / / 56\% } \\
& \text { - papel: } 15.500 \mathrm{mrs} \text { / } 46.920 \mathrm{mrs} \text { / 206\% } \\
& \text { - bonetes: } 52.300 \mathrm{mrs} \text { / } 146.625 \mathrm{mrs} \text { / 180,5\% } \\
& \text { - mercancías del fraile: } 75.000 \mathrm{mrs} \text { / / } 114.100 \mathrm{mrs} \text { / / 52\% }
\end{aligned}
$$

Con todo ese caudal (630.775 mrs.) Iribas rescató a 34 personas, "contenydos en el cuaderno morisco de los del Consejo de las Órdenes»; pagó diversos derechos de saca de 41,5 cautivos; abonó otra cantidad añadida por el cautivo del manyfacto - supongo que para completar el medio cautivo que faltaba-; hizo diversos gastos menores en el taraçanal [atarazanas], barca del Rey y puente de La Goleta, bastajes y guardas de 42 cautivos, y realizó diversos pagos por Valentín de Policasto, cautivo que los de Túnez le habían tomado por la fuerza, para dar presentes en el pleito que se siguió sobre ello. Así pues, rescató 42 cautivos, con lo que el fraile alcanzó a la limosna en 28.265 mrs., todo ello sin contar con el dinero apartado que llevaba para rescatar otras personas por cuenta del Dr. Arcilla. ${ }^{83} \mathrm{~A}$ dicho alcance hubo que sumar 20 ducados de que le hizo merced el Consejo agradecido para sufragar sus gastos de vuelta a su hogar.

Se recuerda al final de esta carta de pago que el mercader genovés Esteban Doria Grimaldo y su compañía, que había recibido de manos del contador Sancho de Paz mil ducados para rescatar cautivos, era quien había remitido a Génova las dos letras de cambio de que se benefició el fraile tudelano, por tanto adeudaba el genovés al Consejo 15.000 mrs.

En conclusión, durante la tercera y cuarta décadas del siglo XVI aún continuó la Orden de Santiago dedicando sus desvelos y recursos al rescate de cautivos; al menos, desde el siglo XIII la Orden disponía de sus propios hospitales para ese fin, al tiempo que aportaba las limosnas de sus vasallos a fin de que los miembros de las órdenes redentoras -mercedarios y trinitarios- realizasen la labor fundamental para la que fueron creadas, todo ello a través de tres vías: las limosnas recaudadas en sus cuestaciones, las bulas predicadas para ello, fueran la de la Merced o la de la Trinidad, y los productos de las obras pías fundadas para la redención por distintos vecinos de la Orden, vía ésta última que sólo se materializaría entrado el reinado de Felipe II.

Respecto a la Orden de Santiago, propiamente dicha, actuaba bien de forma pasiva, concediendo licencias para que los particulares anduviesen pidiendo limosna por su territorio a fin de rescatarse ellos mismos o sus familiares, bien de forma más activa, recaudando penas pecuniarias para ese fin y manteniendo un fondo permanente para ello dentro del Consejo; con esos recursos durante el período de estudio se realizaron numerosos rescates, solicitados de forma individual. Pero los casos más sonados fueron los realizados en el Peñón de Vélez de la Gomera en 1525 y en Túnez, diez años más tarde, que conocemos gracias a haberse conservado las rendiciones de cuentas correspondientes.

83 Llevó 270 escudos, invertidos también en mercancías, que fueron vendidas luego en 517 escudos, de modo que obtuvo un beneficio de $191,5 \%$. 


\section{DOCUMENTO 1}

\section{5/01/26. Madrid}

La quenta que se tomó a Francisco Díaz de la redención de los cabtivos.

Francisco Díaz. Madrid, henero. MDXXV.

AHT, 78.097

Don Carlos, etc. Por quanto Francisco Días, freyle de la dicha Orden, cura de la villa del Corral de Almaguer, admynystrador de los Ospitales de Santiago de los Cavalleros de la cibdad de Toledo e de la villa de Talavera, fue por mi mandado a las partes de allende a rescatar cabtivos de poder de los moros, enemygos de nuestra Santa Fee Cathólica, e por los del my Consejo de la dicha Orden le fue tomada quenta del dicho viaje, el tenor de la qual es este que se sigue:

Relación del cargo que se haze a Francisco Díaz, fleyre de la Orden de Santiago, admynistrador de los Ospitales de Toledo y Talavera, para la cuenta que le fue tomada del viaje que hizo a rescatar cabtyvos de poder de los moros de aliende, enemygos de nuestra Santa Fee Católica, que partyó para ello en fin del mes de agosto del año de quinientos e veynte e quatro.

\section{Cargo}

Primeramente, se le haze cargo de.DCLXXVIMDCCCCLVIII. que le fueron dados por Sancho de Paz y por Pero de Myño, en su nonbre, para la dicha redención, por virtud de una cédula del Enperador e Rey, nuestro señor, admynistrador perpetuo de la Orden de Santiago, de las rentas e penytencias e otras cosas aplicadas para la dicha redinción en la dicha Orden [676.958 mrs.].

Paresce que le costaron .XXXII. paños que conpró para la dicha redención, las .XX. palmyssas, los dos leonados y diez morados, que costaron todos con la tintura de algunos dellos, que se conpraron blancos, e con la tondidura e harpilleras, e de los llevar a Málaga, y por dos myll mrs. que dio a Pero el Pablo, conprador de los dichos paños, .CXLIIIIMDCLXXV., los quales dichos paños fueron vendidos en el precio de los cativos en Bélez de la Gomera, en .IMXXXVII. onças, que montan más .XXXIMDCCCCXLV., de manera que va de ynterese en los dichos paños .CLXXXVIIMCCLXV., de los quales se haze cargo al dicho Francisco Díaz [187.265 mrs.].

Paresce que conpró para la dicha redención .DLXXVII. libras y .VII. onças e [cero] tomynes de seda en madexa, de las quales no vendió ny gastó las .XVI. libras, porque, como estovyeron muchos días después de conpradas en Málaga, dis que estavan dañadas de ratones, y adelante le será fecho alcance de las dichas .XVI. libras [al margen: ojo]; y paresce que toda la dicha seda costó .CCCCVIIMDVI. e medio, e que la vendió en Vélez de la Gomera en el rescate de los cabtyvos en .IIMDCLXVII. onças y un tomín, que montan .DCCCLIIIMCCCCXI., de manera que ovo de ynterese en la dicha seda .CCCCXLVMDCCCCXXXIII. e medio, de los quales se haze cargo al dicho Francisco Díaz [445.933,5 mrs.].

De manera que monta todo el cargo que se haze al dicho Francisco Díaz, ansy de lo que recibió en dinero como de lo que ovo de ynterese en las mercaderías .IQCCCXMCLVI. e medio [1.310.156,5 mrs.].

Data

Para en descuento de los dichos .IQCCCXMCLVI. e medio se reciben en quenta al dicho Francisco Díaz los mrs. syguientes:
Pone el dicho Francisco Díaz que gastó quando vino a la Corte, quando fue llamado para le dar cargo desta negociación, en quarenta y cinco días que estuvo en yda y venyda y estada, a dos reales y medio cada día, .IIIMDCCCXXV. [3.825 mrs.].

Que enbió un mensajero a la Corte desde Quenca por ciertas cédulas para su pasaje, que estuvo .XXV. días, a .LX. cada día, .IMCC. [1.200 mrs.].

Que gastó el dicho Francisco Díaz desde Quenca a Llerena a rescebir los dineros .XXX. días, en yda y venyda y estada, a tres reales, .IIIMLX. [3.060 mrs.].

Que dio a dos honbres que fueron y vinieron con el dos [ducados] [750 mrs.].

Que estuvo en Granada y Málaga para conprar la seda y esperando la respuesta para sy pasaría o no .IIII. meses, a dos reales y medio cada día, .XMCC. [10.200 mrs.].

Que dio al geliz que tiene cargo de la seda en Málaga un ducado, porque le ayudase a comprar la seda e myrase por el peso della, e al çahoracador della otro ducado [750 mrs.].

Que dio a Rodrigo de Xerez porque conprase y escogiese la seda dos ducados [750 mrs.].

Que dio a Christóval de Jaén porque fuese desde Málaga a Vélez de la Gomera y a Fez por seguro para el pasaje .II. ducados [750 mrs.].

Que enbió un moço desde Granada a la Corte por ciertas escripturas y para saber sy pasaría o no, porque los flayres de la Trenydad estavan aliende; que estuvo en yda y venyda y estada .LX. días, a .XXX., .IMDCCC. [1.800 mrs.].

Que dio a un moço que le syrvió los dichos .LX. días, quatro ducados [1.500 mrs.].

Que pagó a dos escrivanos porque fizieron los testimonyos de cómo se avían encarescido aliende los cabtyvos, .CLXX. [170 mrs.].

Que dio al alguazil y porquerones que fueron a sacar la seda de casa del geliz e aduana de la seda, donde estava, para poner en poder de Rodrigo Álvarez, donde quedó deposytada, real y medio [51 mrs.].

Que dio a un letrado que ordenó los requerimientos, quatro reales [136 mrs.].

Que dio por los derechos de una provysyón que sacó en Granada sobre el pagar de los derechos a los arrendadores, .CLXX. [170 mrs.].

Que dio a otro letrado que or[denó] e solicitó la dicha provisyón, quatro reales [136 mrs.].

Que fue desde Málaga a Burgos para fazer relación de lo que tenya fecho y conprado; que estuvo en yda y venyda y estada.XXXV. días, a dos reales y medio, .IIMCCCCLXXV. [2.475 mrs.].

Que enbió un mensajero a la Corte a faser saber cómo la seda y paños se perdían, para saber sy mandavan que fuese a fazer el rescate; que estuvo en yr y en venyr .XX. días, a .LX. cada día, .IMCC. [1.200 mrs.].

Que partió de Toledo para yr a Quenca a tomar los paños, que estuvo en yda y venyda y estada .XX. días, a dos reales y medio, .IMDCC. [1.700 mrs.].

Que estuvo en el camyno desde Quenca a Málaga .XIII. días, porque yva con los recueros que llevavan los paños, a tres reales cada día, .IMCCCXXVI. [1.326 mrs.].

Que estuvo en Málaga fasta el día que se enbarcó y partió .LXVIII. días, que gastó a dos reales y medio cada día, .VMDCCLXXX. [5.790 mrs.]. 
Que enbió un moço a la Corte quando se partyó para allende, .Il. ducados [750 mrs.].

Que dio a un letrado que le ayudó en Málaga a los pleytos que tuvo sobre el enbarcar de la seda y paños, un ducado [375 mrs.].

Que dio al acesor de los juezes que avían de dar la sentencia con el alcalde de la seda, un ducado [375 mrs.].

Que dio a Juan Parado y a Portillo, escrivanos de Málaga, ante quyen pasaron los pleytos, y juezes y alguaziles que fueron a sacar la ropa para la enbarcar, que estava deposytada, dos ducados [750 mrs.].

Que le costó el navío en que pasó, sólo el caxco d’él, .VIIIMDCCCCLXXXII. [8.982 mrs.].

Que llevó un piloto, que ganava cada mes seys ducados, y un arraez, que ganava por el primer mes tres ducados, y tres marineros, que ganavan a .DCCCCL. cada mes, y de comer a los unos y a los otros, que gastó en dos meses él y la gente que llevava en yda y venyda y estada.XXIXMDXCIX. de toda costa fasta bolver a Málaga, con un ducado cada mes que dava a un moço que servía a los marineros [29.599 mrs.].

Que costaron .IIII. bestias en que troxo desde Málaga a Toledo tres mugeres y un niño cabtyvos y el hato, .IIIMCLXII. [3.162 mrs.].

Que costó la vandera con las armas reales y ávito de Santiago y ávitos de los cabtyvos y una crus, .DCCCCLVIII. [958 mrs.].

Que costó una vara de lança para la vandera, .LX. [60 mrs.].

Rescató el dicho Francisco Díaz .XLV. cabtyvos cristianos, honbres y mugeres, los quales costaron a diversos prescios, demás de algunas ayudas que los mysmos cabtyvos e otras personas les fizieron, .IIIMCCLVIII. onças y media de plata, que valen a .CCCXX. cada onça, en que montan .IQXLIIMDCCXX., según que todo lo contenido en este capítulo constó e paresció por testimonyo synado de escrivano y de dos escrivanos del Rey moro, el uno moro y el otro judío. Todos los quales dichos cabtivos paresce ansy mysmo por testimonio que traxo y desenbarcó en la cibdad de Málaga, en tierra de christianos [1.042.720 mrs.].

Que pagó de derechos al Rey moro de Vélez de la Gomera, a ocho por ciento de las dichas mercaderías, que montaron los dichos derechos .LXXXIIIM-CCCCLXXX. [83.480 mrs.].

Que dio al almoxarife de Vélez de sus derechos de cada cabtivo onça y media de plata, que montan .XXIMDCL. [21.650 mrs.].

Que pagó al almyrante e alcayde de la mar de Vélez de la Gomera de cada cabeça de cabtivo media onça, que montan .VIIMCC. [7.200 mrs.].

Que pagó a maestre Abrahán judío, escrivano del Rey moro, un tomyn de cada cabeça de cabtyvo, que montan .IMDCCCCLX. [1.960 mrs.].

Que dio a Gaspar de Santistevan, vezino de Málaga, que fue con el dicho Francisco Díaz a Vélez a entender en los prescios de los cabtivos, porque entendía la lengua de los moros, y para pesar la seda y hazer la quenta con los moros, .X. ducados [3.750 mrs.].

Que dio a un honbre que fue con el dicho Francisco Díaz desde Toledo, que llevava cargo de dar recabdo y quenta de la fazienda e a la gente en la nao y fuera della, cada mes dos ducados, por asyento desde en principio de agosto fasta en fyn de enero, que montaron .IIIIMD. [4.500 mrs.].

Que dio a otro moço de servir, que fue con él por el dicho tienpo, quatro ducados [1.500 mrs.].

Que dio a Martín Sanches, vezino de Málaga, quatro ducados, porque fue a Vélez de la Gomera a traer otro seguro, porque quando llegó a Málaga halló que avía venydo allí un judío del Rey moro de Vélez a cobrar ciertos dineros que se devían al dicho Rey moro y que no lo dexaron yr a Sevilla ni a Granada, y temiendo que por esto le hiziesen alguna represaria, enbyó por el dicho seguro [1.500 mrs.].

Que gastó un moço que enbyó desde Málaga a la Corte sobre el enbargo que le hizieron por los derechos, .IMCC. [1.200 mrs.].

Que dio a Mosén Capez judío, que fue a Barraos y a Melilla a traer dos cabtivos y a fablar al alcaide de Melilla, y el alcaide le detuvo .XXX. días, .VI. onças [1.920 mrs.].

Que dio a un cirujano en Vélez, porque curó un cabtyvo que se cortó un dedo serrando, una onça [320 mrs.].

Que fizo de costa el dicho Francisco Díaz y los dichos .XLV. cabtyvos desde Málaga fasta llegar a la Corte .VIIMD. [7.500 mrs.].

Que costaron dos carretas en que traxeron las mugeres y niño y coxos desde Toledo a Madrid .II. ducados [750 mrs.].

Que dexó deposytados en Málaga, en poder de Gaspar de Santistevan armador, .LXIIIMDLXXX., fasta que se determine sy se deven pagar derechos de las dichas mercaderías o no [63.580 mrs.].

De manera que montan los mrs. que el dicho Francisco Díaz ha gastado e se le resciben en quenta en la manera que dicha es, .IQCCCXXVIMDXC. [1.326.590 mrs.]

De manera que alcança el dicho Francisco Díaz a la dicha redención por .XVIMCCCCXXXIII. e medio [16.433,5 mrs.].

Y quedan para la redención las .XVI. libras de seda que quedaron en Málaga, en poder de Alonso de Montalván mercader, vezino de Toledo, que no se gastaron porque estavan dañadas e ansy mysmo los .LXIIIMDLXXX. del depósito que quedó hecho en Málaga, sy se pudieren desenbaraçar.

Alcance fynal

Del qual dicho alcance de los dichos .XVIMCCCCXXXIII. e medio se desquentan .XIIMCCCCXXXIII. e medio por razón que algunos de los gastos que el dicho Francisco Díaz fizo estando en Vélez de la Gomera, especialmente, en cosas de mantenimientos e de otras cosas semejantes, se hizieron a respeto del prescio de las mercaderías e le están rescebidos en quanto a respeto de dineros de Castilla y en esto puede aver de ynterese los dichos .XIIMCCCCXXXIII. e medio, por manera que queda el dicho alcance que el dicho Francisco Díaz haze contra la dicha redención en .IIIIM. [4.000 mrs.].

A agora el dicho Francisco Díaz me suplicó e pidió por merced le mandase dar la dicha quenta e fin e quyto della para que en todo tienpo le fuese guardada, o como la mi merced fuese, e Yo, con acuerdo de los del dicho my Consejo, tóvelo por bien e por la presente apruevo e confirmo la dicha quenta que de suso va yncorporada, por buena y verdadera y mando que valga e sea guardada al dicho Francisco Díaz para siempre jamás, e que en ella ny en cosa ni parte della le sea puesto enbaraço ni enpedimiento alguno, de lo qual le mandé dar esta mi carta, librada en el dicho mi Consejo 
e sellada con mi sello de la dicha Orden. Dada en la villa de Madrid, a veynte y seys días del mes de henero, año de mill e quinientos e veynte e cinco años. Hernando de Vega, comendador mayor. Licenciatus Luxan. D. Florez licenciatus. Secretario, Guerrero.

\section{DOCUMENTO 2}

\section{6/02/01. Toledo}

Para que se aya cierta ynformación sobre los cautivos por quien pide limosna Juan de Oribe.

Ciertos cabtyvos. Toledo, hebrero de .DXXVI.

AHT, leg. 78.110

Don Carlos, etc. A vos los nuestros corregidores y otras qualesquer justicias de las cibdades de Cáliz e Almería y de las villas de Tarifa y del Puerto de Santa María y de otras qualesquyer cibdades, villas y logares destos Reynos e señoríos de Castilla, e a cada uno y qualquier de vos, en vuestros lugares e jurisdiciones, que con esta mi carta fuéredes requeridos. Salud e gracia.

Sepades que Juan de Oribe, vezino de la dicha villa de Tarifa, por sy y en nonbre de Garlos de Alicante, vezino de la cibdad de Almería, y de Antón Sánchez, vezino de la dicha cibdad de Cáliz, e de Alonso de Burgos, natural de la cibdad de Burgos, e de Melchor Díaz e Lorenço Hernandes e Antonio Gonçález e Martín Alonso e Gaspar Hernández e Martín Vázquez, vezinos y abitantes que an sydo en la dicha villa del Puerto de Santa María, me hizo relación por su petición, que en el mi Consejo de la dicha Orden presentó, diziendo que ellos están cabtivos en poder de los moros de allende, enemygos de nuestra Santa Fee Cathólica, e que porque son pobres e no tienen con qué se rescatar, me suplicavan e pedían por merced les mandase faser merced e limosna de la cantidad de mrs. que oviesen menester para su rescate, o como la mi merced fuese.

Y en el dicho mi Consejo fue acordado que devía mandar dar esta mi carta para vos en la dicha razón e Yo tóvelo por bien, por la qual vos cometo y mando que como con ella fuéredes requerido, vosotros por vuestras personas, syn lo cometer a otro alguno, cada uno en su juridición, ayáys ynformación e sepáys sy los susodichos están cabtivos en poder de los dichos moros e qué tanto tienpo ha que los cabtivaron y en qué lugares y en poder de qué personas están e qué bienes rayzes y muebles tiene cada uno dellos e lo que pueden valer e sy algunos de los susodichos e quáles están rescatados o tienen padres e madres que puedan buenamente rescatarlos e cómo se llaman e dónde son vesinos e qué bienes e hazienda tiene cada uno dellos e de todo lo demás que cerca de lo susodicho vos parezca devo ser ynformado, firmada de vuestros nonbres, sygnada, cerrada e sellada, en manera que haga fee, la hazed dar y entregar al dicho Juan de Oribe o a quyen su poder oviere, para que lo trayga e presente en el dicho mi Consejo e Yo lo mandaré ver e proveer sobre ello lo que deva ser proveydo, para lo qual, sy nescesario hes, vos do poder cunplido, con sus yncidencias e dependencias, anexidades e conexidades, e no fagades ende al. Dada en Toledo, a primero de hebrero de.DXXVI. Luduvicus licenciatus. Licenciatus Luxan. Fortunus d’Ercilla. Secretario, Guerrero.

\section{DOCUMENTO 3}

\section{6/04/28. Sevilla}

Al governador de la provincia de León o su tenyente, aya cierta ynformación sobre los qu'están cabtivos y la enbíe al Consejo.

De oficio. Sevilla, abril de .DXXVI.

Diose otra tal para el governador del Canpo de Montiel e las Syerras.

Y otra para el del partido de la Mancha e Ribera de Tajo del mismo thenor e fecha.

AHT, leg. 78.112

Don Carlos, etc. A vos el my governador de la provincia de León o a vuestro logartenyente en el dicho oficio. Salud e gracia.

Sepades que en el my Consejo de la dicha Orden ay diputadas ciertas quantías de mrs. para redención de cabtivos christianos qu'están en poder de los moros de allende, enemygos de nuestra Santa Fee Católica, y porque yo quiero ser ynformado sy ay algunas personas, vezinos o naturales de la tierra de la dicha Orden, qu'estén en el dicho cabtiverio, fue acordado en el my Consejo della que devía mandar dar esta my carta para vos en la dicha rasón, e Yo tóvelo por bien, porque vos mando que luego como la recibáys os ynforméys e sepáys con toda la diligencia sy ay algunas personas, honbres o mugeres, vesinos o naturales desa dicha provincia, que al presente estén cabtivos en poder de los dichos moros e quyén son e cómo se llaman e dónde son vezinos o naturales e qué hedad e calidad tiene cada uno e qué tanto tienpo ha qu'están en el dicho cabtiverio y en qué villa o logar y en cuyo poder e adónde fueron cabtivos e sy tienen bienes muebles o rayses e qué bienes son e lo que podrá valer lo que cada uno tiene e sy por su parte se ha hablado en sus rescates e sy están concertados en ellos e por qué quantía e de qué manera e sy han pagado alguna parte de los tales rescates e lo que dellos restán deviendo, declarando cada cosa por sy particularmente, e de todo lo demás que cerca dello os paresca deva ser ynformado, e asy avida la dicha ynformación, firmada de vuestro nonbre, cerrada e sellada, en manera que faga fee, la enbiad luego al dicho my Consejo para que Yo la mande ver e proveer sobrello lo que deva ser proveydo, en no fagades ende al. Dada en Sevilla, a .XXVIII. de abril de .DXXVI. El conde don García Manrique. Luduvicus licenciatus. Licenciatus Luxan. D. Florez licenciatus. Fortunus d'Ercilla. Secretario, Guerrero.

\section{DOCUMENTO 4}

$1527 / 02 / 21$. Valladolid

Fin e quyto para Francisco Díaz, admynystrador del Ospital de Santiago de Toledo, de lo que dicho Ospital devió pagar para redención de cabtyvos los tres años de.DXXIII. y .XXIIII. y .XXV.

El administrador de Santiago de la cibdad de Toledo. Valladolid, hebrero de .MDXXVII.

AHT, leg. 78.122

Don Carlos, etc. Por quanto el Ospital de Santyago de los Cavalleros de la cibdad de Toledo fue obligado a pagar cinquenta myll mrs. para redinción de cabtivos en cada uno 
de los tres años pasados de quinientos e veynte e tres e quinientos e veynte y quatro e quinientos e veynt y cinco, que montó todos tres años ciento e cinquenta myll mrs., de los quales Yo enbíe a mandar por una my cédula a Francisco Díaz, fleyre de la dicha Orden, administrador del dicho Ospital, que enbiase la quenta y razón al my Consejo de las Órdenes, e que ansy mysmo enbiase los mrs. que toviese por pagar al dicho my Consejo, y el dicho Francisco Díaz enbió la dicha quenta, por la qual se hizo cargo de los dichos ciento e cinquenta myll mrs. que ovo de dar para la redención de los dichos cabtyvos, de las rentas del dicho Ospital, los dichos tres años de quinientos e veynte e tres e quinientos e veynt y quatro e quinientos e veynte e cinco, conviene a saber e cada uno de los dichos años cinquenta myll mrs.

Data

Para en quenta y descargo de los dichos ciento y cinquenta myll mrs. el dicho Francisco Díaz mostró aver dado e pagado los mrs. que adelante dirá en esta guisa:

A Miguel de Estrada, vezino de Úbeda, por [cédula] de S.M., fecha a veynte días del mes de mayo de quinientos e veynte e quatro años, treynta myll mrs. para ayuda al rescate de Bartolomé de Biedma e de Francisco Dorador, vezinos de Vedmar [30.000 mrs].

A Antonio de Ahumada, vezino de Medina de Rioseco, por cédula de S.M., fecha a .XXV. de agosto de .DXXV. años, nueve myll e seyscientos mrs. para ayuda al rescate de Alonso de Ahumanda cabtyvo [9.600 mrs.].

A Bartolomé Sánchez de Anguyto, vezino de la Torre don Ximeno, por mandamiento de los señores del Consejo, fecha a veynt e tres días de junyo de quinientos e veynt e seys años, nueve myll e seyscientos mrs. para ayuda al rescate de Juan de Anguyto, su hijo, cabtivo [9.600 mrs.].

A Antonyo de Valderrábano, fiscal de la dicha Orden de Santyago, para prosecución de un pleyto que trata ante los contadores mayores sobre los derechos de la seda que se conpra para redinción de cabtyvos, diez e ocho reales, por mandamiento de los del dicho Consejo, fecho a syete días de otubre de quinientos e veynt e cinco años [612 mrs.].

Se le resciben en quenta nueve myll mrs. que mostró que Pero Hernández de Busto, cavallero de la dicha Orden, avía rescebido en quenta a Gómez de Tévar, administrador que fue del dicho Ospital antes del dicho Francisco Díaz, en una quenta que le tomó de los dineros de la dicha redinción por mi comisyón, porque halló qu'el dicho Gómez de Tévar los avía pagado por my libramiento a Juan de Rubadeneyra, vezino de Málaga, de los mrs. que el dicho Ospital fue obligado a pagar para la dicha redinción el dicho año de quinientos e veynt e tres, y rescíbensele en quenta al dicho Francisco Díaz porque le están cargados todos los dichos cinquenta myll mrs. del dicho año [9.000 mrs.].

Yten, se le resciben en quenta dos ducados que dio e pagó por mandado de los del my Consejo a Nycolás Martínez, fleyre de la dicha Orden, porque traxo al dicho my Consejo la dicha quenta e los mrs. que restavan en poder del dicho Francisco Díaz [750 mrs.].

Yten, se les resciben en quenta ciento y dos mrs. que dio e pagó por los traslados de ciertas cédulas e provisyones y escripturas tocantes a la dicha quenta [102 mrs.].

Por manera que montan los mrs. de la dicha data en la manera que dicha es, cinquenta y nueve myll y seyscientos y sesenta y quatro mrs. [59.664 mrs.].
Los quales dichos cinquenta y nueve myll y seyscientos e sesenta y quatro mrs. de la dicha data, quitos e descontados de los dichos ciento y cinquenta myll mrs. del cargo, finca alcançado el dicho Francisco Díaz por noventa myll e trezientos e treynta y seys mrs. [90.336 mrs.].

Los quales dichos noventa myll e trezientos e treynta y seys mrs. del dicho alcance del dicho my Consejo mandaron de my parte al dicho Francisco Díaz que los diese y pagase a Sancho de Paz, my contador de la Orden de Alcántara, y paresce por conoscimiento del dicho Sancho de Paz avérselos dado y pagado, de manera qu'el dicho Francisco Díaz no resta deviendo cosa alguna de los dichos ciento y cinquenta myll mrs. qu'el dicho Ospital fue obligado a pagar para la dicha redinción los dichos tres años de quinientos e veynt e tres e quinientos e veynt e quatro e quinientos e veynt e cinco años, por ende, por la presente doy por libre e quyto al dicho Ospital y al dicho Francisco Díaz, en su nonbre, de los dichos ciento y cinquenta myll mrs.

De lo qual mandé dar esta my carta librada en el my Consejo de la dicha Orden, e sellada con my sello della. Dada en Valladolid, a .XXI. de hebrero de .MDXXVII. años. El conde don García Manrique. Luduvicus licenciatus. Licenciatus Luxan. Fortunus d'Ercilla. Secretario, Guerrero.

[Membrete] Mynuta del finyquyto que se ha de dar a Francisco Díaz de los mrs. que el Ospital de Santiago fue obligado a pagar ciertos años para redención de cabtyvos.

\section{DOCUMENTO 5}

\section{5/09/18. Madrid}

Quenta que se tomó a fray Joan de Yribas de la redención de los cativos.

Joan de Yrivas. Madrid, setienbre, año de .MDXXXV.

AHT, leg. 78.225

Don Carlos, etc. Por quanto fray Joan de Yribas, comendador de Santi Nycasio de la cibdad de Tudela de Navarra, fue por mi mandado a las partes de allende a rescatar cabtivos de poder de los moros, henemigos de nuestra Santa Fee Católica, e por los del my Consejo de la dicha Orden le fue tomada quenta del dicho viage, el thenor del qual es este que se sigue:

Relación del cargo que se haze a fray Joan de Iribas, comendador de Santi Nycasio de la cibdad de Tudela de Navarra, para la quenta que le fue tomada del viage que hizo a rescatar cativos de poder de los moros de allende, henemigos de nuestra Santa Fee Católica, que partió para ello.

\section{Cargo}

Primeramente, se le haze cargo de veynte ducados en oro, que rescebió de mano del doctor Arzilla, que sea en gloria, que valen a moneda de Génova, contando a setenta y dos sueldos por ducado, reduzidos a libras en la mysma moneda, contando veynte sueldos por libra, que son los dichos veynte ducados, setenta y dos libras [72 libras / 7.500 mrs.].

Paresce que rescebió una cédula de cambio del dicho dottor Arcilla, diregida a Joan Baptista de Grimaldo, en Génova, de quatrocientos y ochenta ducados, los quales ovo de ganancia un sueldo por ducado, y ansy monta, contando 
a setenta y tres sueldos por ducado, myll y setecientos y cinquenta y dos libras, con la ganancia del sobredicho sueldo [1.752 libras / $182.550 \mathrm{mrs}$.].

Que rescebió más otra cédula de cambio, que los del Consejo de las Ordenes y el dicho doctor Arcilia dieron a Hortuño de Hecheaga, de quatrocientos y sesenta ducados, en los quales no ovo ganancia alguna, y contando como valer, como dicho es, son [1.656 libras / 172.500 mrs.].

De manera que monta todo el cargo que se haze al dicho fray Joan de Yribas de todo lo que rescebió trezientas y sesenta y dos myll y quinientos y cinquenta mrs., que suman a moneda de Génova tres myll y quatrocientas y ochenta libras [3.480 libras / 362.550 mrs.].

\section{Data}

Para en descuento de este dicho cargo, se lee resciben en quenta al dicho fray Joan los mrs. siguientes:

Pone que conpró trezientas dozenas de bonetes berberiscos colorados, para llevarlos a Tunes, que costaron ciento e quarenta e cinco escudos y medio, que son de moneda de Génova, contando a sesenta y nueve sueldos por escudo, montan quynyentas y una libra y diez y nueve sueldos y seis dineros, valen cinquenta e dos myll e trezientos maravedís [501 libras, 19 sueldos y 6 dineros / 52.300 mrs.].

Compró más treynta y syete libras de oro hilado, que costó a nueve escudos y un quarto la libra, que son al prescio susodicho, con un escudo que pagué al corredor por sus derechos, monta myll y ciento y ochenta y quatro libras y quatro sueldos y tres dineros, valen [1.184 libras, 4 sueldos y 3 dineros / 123.390 mrs.].

Más conpró ciento y treynta libras y media de corales, que costaron a tres libras y onze sueldos la libra, con dos libras que dio al corredor por sus derechos, que son quatrocientas y sysenta y cinco libras y cinco sueldos y seis dineros, valen quarenta y ocho myll y quatrocientos y ochenta mrs. [465 libras, 5 sueldos y 6 dineros / 48.480 mrs.].

Compró más diez pieças de paños de Florencia, de Génova, de diversas colores, que costaron a ochenta libras cada pieça, que montan 800 libras, que valen ochenta y tres myll y trezientos y sesenta mrs. [800 libras / 83.360 mrs.].

Que pagó por doze valas de papel, cencilias, de estraça, que costaron a setenta y tres sueldos por vala, y más en comprar otras veynte y ocho balas del dicho papel, que costaron a setenta y nueve sueldos por bala, que montaron las dos partidas de las susodichas veynte balas cencilyas ciento y quarenta y ocho libras y seis sueldos, valen [148 libras y 6 sueldos / $15.500 \mathrm{mrs}$.].

Yten, conpró una arca con dos llaves para llevar el oro hilado y los corales, que costó cinco libras [y] diez y ocho sueldos, valen [5 libras y 18 sueldos / 602 mrs.].

Que pagó en Génova por los derechos de los bonetes y del papel, es a saber, por el derecho del comercio que tienen de derecho cinco por ciento y por el derecho de la Berbería a tres y medio por ciento, que son ocho y medio por ciento, que será la suma de los bonetes y papel, que montan seyscientas y cinquenta libras, seys sueldos y dos dineros, vienen al respeto cinquenta e cinco libras, seis sueldos, dos dineros; pero hízoseme gracia de esta suma de la mayor parte, porque se estimó la dicha ropa en ciento y noventa libras y no más; esto por respeto e yntercesión de Joan Baptista, por los quales pagué con seis dineros, que dy al sello, diez y seis libras, tres sueldos y seis dineros y más pagué por el derecho de la ripia genesa de los bonetes quatro libras y diez sueldos, monta todo veynte libras, treze sueldos y seis dineros, valen [20 libras, 13 sueldos y 6 dineros / $2.153 \mathrm{mrs}$.].

Que pagó en Génova por llevar el papel de extraça a la marina para cargar en la barca para enbiarlo a Liorna, a los bastages, catorze sueldos, valen [14 sueldos / $73 \mathrm{mrs}$.].

Que dio por el flete de los bonetes, por llevarlos de Saona a Génova, diez y seis sueldos [16 sueldos / 83 mrs.].

Que pagó por la correduría de las quarenta balas de papel sencilias al corredor por sus derechos, catorze sueldos, valen [14 sueldos / $73 \mathrm{mrs}$.].

Que conpró en Génova cordeles y cañamaza para atar y fazer balas de las diez pieças de paños y al ligador por su trabaxo, monta todo quatro libras, cinco sueldos [4 libras y 5 sueldos / $444 \mathrm{mrs}$.].

Que pagó por el dicho comercio en Génova de los corales y paños, que pagan a cinco por ciento, myll y docientas y sesenta y cinco libras, cinco sueldos y seis dineros, en que montan a los dichos corales y paños, que les vienen de derechos sesenta y cinco libras y syete sueldos, pero hízoseme gracia la mayor parte de esta suma por el medio que dimos entre Juan Baptista e yo, por su respeto pagó tan solamente seis libras, diez y nueve sueldos y un dinero, valen [6 libras, 19 sueldos y un dinero / 725 mrs.].

Que pagó a Estéfano Bargadio Sauli porque le ayudó a comprar toda la mercaduría y le enderesçó en todo lo nescesario, que, si no fuera por él, podiéranle decebir y engañar, por no saber la plática, seis escudos; la qual mercaduría montó tres myll y setecientas y diez y syete libras y onze sueldos, que bien va un dinero y cinco dozavos de dinero por libra, que contando al respeto a las tres myll y cient libras y cinco sueldos y tres dineros de esta quenta, que monta la mercaduría, viénenle diez y ocho libras, tres sueldos y cinco dineros [18 libras, 3 sueldos y 5 dineros / $1.893 \mathrm{mrs}$.].

Que pagó más por el derecho de Berbería por los corales y oro hilado y paños, que montan en suma 2.449 libras y nueve sueldos y nueve dineros, que tienen de derecho a tres y medio por ciento, que le viene ochenta y cinco libras y quinze sueldos, enpero hízosele gracia de la mayor parte, que por toda la mercaduría susodicha con los rodeos e yntercesyón de Juan Baptista no pagó syno tan solamente treynta y dos libras, treze sueldos y onze dineros, valen [32 libras, 13 sueldos y 11 dineros / 3.400 mrs.].

Que pagó en Génova por el derecho de la cencería, que es por la saca de la cibdad, por los paños, una libra e diez y seis sueldos e nueve dineros [una libra, 16 sueldos y 9 dineros / 193 mrs.].

Que pagó en Génova el dicho fray Joan de Yribas por llevar los paños y la caxa y la otra mercaduría y otras menudencias de su persona, de su posada a la marina, al muelle, para envarcar a los ganapanes, doze sueldos [12 sueldos / $62 \mathrm{mrs}$.].

Que pagó en Génova a Jacobo Villamarín notario por el testimonyo sellado de la fee de la mercaduría, dos libras y diez y ocho sueldos, valen moneda castellana [2 libras y 18 sueldos / 300 mrs.].

Que pagó más en Génova, a diez y ocho de noviembre, a Grigorio Espínola Picaluga notario, por un poder que hizo a Joan Baptista de Grimaldo para que, en casso que en su 
ausencia o por cassos fortuytos, alguna cosa le acahesciese, para demandar la fazienda asegurada, etc. quatro sueldos [4 sueldos / $21 \mathrm{mrs}$.].

Que pagó en Génova por el nolito de cierta mercaduría que llevó de Génova a Liorna, que es en suma de tres myll y cinquenta y seys libras y onze sueldos y seis dineros, en los quales no ovode la mercaduría de esta quenta, syno dos myll y quatrocientas y quarenta y nueve libras y diez sueldos y seis dineros, que son corales y oro hilado $y$ paños; pagué quatro escudos, que viene a un dinero y tres veyntequatrabos de dinero por libra, monta por rata por el dicho oro, corales y paños, onze libras y doze sueldos [11 libras y 12 sueldos / $1.208 \mathrm{mrs}$.].

Que pagó por el nolito de los bonetes y papel, de Génova a Liorna, seis escudos, que son veynte libras y catorze sueldos [20 libras y 14 sueldos / 2.157 mrs.].

Que pagó en Liorna por entrar la mercaduría que llevava de la Puente a la Aduana, por los derechos de la Casa de la Aduana, tres escudos, la qual mercaduría hera de la suma de tres myll y onze libras y tres dineros, que por rata le viene a la mercaduría de esta quenta siete libras, quatro sueldos y un dinero [7 libras, 4 sueldos y un dinero / 750 mrs.].

Que pagó el dicho fray Juan de Yribas quando fue tras la nave fasta Popolonya y de ay bolvió a Liorna, y como por estonces cessó el pasage de Túnez en el dicho navío, e después encomendó la dicha mercaduría en la antedicha Casa del Aduana y ansy por descargar y llevar al Aduana, como después por tornarla a llevar a la Puente, pagó a los ganapanes una libra y cinco sueldos, valen [una libra y 5 sueldos / 132 mrs.].

Que pagó a veynte y ocho de novienbre a un correo que enbió de Liorna a Juan Baptista de Grimaldo para que le enbiase ciertas cartas de favor, para que le acoxesen en la nao que se partía a Túnez, al qual le dio dos escudos, que son seis libras y diez y ocho sueldos [6 libras y 18 sueldos / $718 \mathrm{mrs}$.$] .$

Que pagó en postrero de novienbre a los varqueros dos escudos y medio por llevarle en una fragata tras la nave con la mercaduría que le ofrecieron de llevar y alcançar la dicha nave, y ansy corrieron con la mercaduría desta quenta fasta Popolonia y de ay bolvyeron a Liorna, porque no quyso esperar la nave, que monta ocho libras, doze sueldos y seis dineros [8 libras, 12 sueldos y 6 dineros / 898 mrs.].

Que pagó treynta sueldos de flette desde Liorna a Génova, que fue por mar, dexada la mercaduría en Liorna, por buscar pasage para Túnez, y dio a los varqueros una libra y diez sueldos [una libra y 10 sueldos / 153 mrs.].

Que pagó el dicho fray Juan de Yribas quando fue de Génova a Liorna la postrera vez por la mercaduría para traerla a Génova, que alló pasage, ansy en cavalgaduras como en varcas, nueve libras y siete sueldos [9 libras y 7 sueldos / 874 mrs.].

Por llevar los bonetes, paños y papel y la caxa de los corales y oro ylado, que lo llevó desde Liorna hasta Génova en un alaúd y dos fragatas, pagó de flete nueve escudos y medio, que son treynta y quatro libras y quinze sueldos y seis dineros, valen [34 libras, 15 sueldos y 6 dineros / 3.623 mrs.].

En Génova, por pato que hizo con los mercaderes, de un derecho que se paga, que dizen de la censería, que es por cargar la mercaduría en qualquyer nave o baxelo, por yntercesión de Joan Baptista de Grimaldo pagó tan solamente dos libras [2 libras / 209 mrs.].

Que pagó en Túnez flete de la mercaduría de esta quenta desde Génova fasta Túnez, sesenta y quatro escudos y veynte y un sueldos y seis dineros, que son docientas y veynte y una libras e diez y siete sueldos y seis dineros [221 libras, 17 sueldos y 6 dineros / $23.118 \mathrm{mrs}$.].

Que pagó por el seguro de la mercaduría que llevó en el el galeón de Génova fasta Túnez y lo pagó Joan Baptista de Grimaldo al corredor, cient escudos; el qual seguro se hizo en dorma de quatro myll y ciento y nueve libras y tres dineros, que viene a veynte dineros y un veyntequatrabo de dinero por libra, que a la mercaduría de esta quenta, que suma tres myll y cient libras y cinco sueldos y tres dineros, por ratta le viene docientos y cinquenta y nueve libras y dos dineros, valen [259 libras y dos dineros / 26.988 mrs.].

Que pagó más por una mula, que se le murió en Villafranca de Nyça, la qual tenya prestada del comendador de Sangüesa de Navarra, por la qual le pagó veynte escudos, aunque a la verdad valía más, que son sesenta y nueve libras, que valen [69 libras / $7.190 \mathrm{mrs}$.].

Lo qual an de pagar los señores del Consejo y el dottor, que gastó el dicho fray Joan de Yribas en cosas para su persona y servicio, nescesarias para el viage que yba y de alquileres de cavalgaduras después que se le murió la mula en Villafranca, por fletes de fragatas de Villafranca hasta Génova y de Génova a Pisa y a Liorna, en las dos primeras que fue syn la postreras, treynta libras y un sueldo y seis dineros, los quales se an de repartir entre los del Consejo y el doctor Arcilia, porque por todos hera la jornada, y la parte porción qu'el dicho dottor a de pagar se remyte al conde de Osorno y sus colegas, monta el gasto lo que dicho es [30 libras, un escudo y 6 dineros / 3.130 mrs.].

Que pagó por el flette de quarenta y dos cativos de Tunes fasta Nápoles, que hizo prescio y yguala que daría a dos escudos por cada persona, pagué catorze escudos y la resta, que son setenta escudos, se pagaron de cierta limosna quel Visorrey y los del Consejo de Nápoles y otras personas particulares de la cibdad en limosna dieron, y a esta causa no hago cargo, syno de lo que yo pagué, que son quarenta y ocho libras y seis sueldos [48 libras y 6 sueldos / 5.032 mrs.].

Que pagó por el flette de su persona desde Túnez fasta Marçara, qu'es en Cecilia, tres escudos y medio, que son doze libras y un sueldo y seis dineros [12 libras, un sueldos y 6 dineros / $1.250 \mathrm{mrs}$.].

Que pagó desde Cecilia a Nápoles por el flette de su persona y de Nápoles fasta Barcelona, diez escudos, que tanbién al dicho dottor cabe su ratta parte, como los del Consejo hordenaren, que son treynta y quatro libras y diez escudos [34 libras y 10 escudos / 3.595 mrs.].

Que conpró en Barcelona una aca de medida para venyr a la Corte, adonde estavan los sobredichos del Consejo, a dar quenta de lo que avía hecho por su mandado, que le costó veynte e cinco escudos; la qual tiene en su poder fasta fazer la voluntad de los del Consejo; valen ochenta y seis libras y cinco sueldos, que son [86 libras y 5 sueldos / 8.985 mrs.].

Más se le pasa en quenta que gastó de la costa de su persona desde el día que partió de la dicha su encomienda de Tudela de Navarra, que fue a onze de junyo de myll e quynyentos e treynta e tres años, por mandado del dicho dottor para Madrid, donde al presente estava la Corte de 
S.M., y de Madrid partió a veynte e quatro de junyo del dicho año, por mandado del dicho dottor Arcilia y en nonbre de los dichos del Consejo de las Órdenes para hefeto de la susodicha redención; en el qual viage estuvo en Génova y Liorna y otras partes, conprando mercadurías y buscando viage de naos para pasar a Túnez fasta quinze de hebrero de quynyentos e treynta y quatro, que llegó a la dicha cibdad de Túnez, que son ocho meses y tres días; en este tienpo en parte del camyno tuvo la costa de su persona y moço y cavalgadura y gastó cinco escudos por mes, que montan a onze sueldos y medio por día, que son en los dichos ocho meses y tres días, ciento y treynta y nueve libras y catorze sueldos y seis dineros, de los quales al dicho dottor cabe su ratta parte [139 libras, 14 sueldos y 6 dineros / 14.560 mrs.].

Más se le descarga que gastó en la costa de su persona en Túnez, desde quinze de hebrero del dicho año de quynyentos e treynta e quatro fasta nueve de dizienbre del dicho año, que partió de Túnez para tierra de christianos y a onze del dicho mes salió a Marçara, tierra de Cecilia, donde estuvo fasta onze de dizienbre, que son nueve meses y veynt e seis días, por los quales cuenta la costa personal cinco escudos por mes, aunque gastava más por la carestía del vino, pero por cierta dieta que por no poder más tuvo, se quita, ansy que son ciento y sesenta libras y quatro sueldos, que valen en moneda genovesa, que tanbién al dicho dottor le cabe su ratta parte [160 libras y 4 sueldos / 16.693 mrs.].

Que gastó en Cecilia por la costa de su persona y un moço que tomó y en Nápoles y otras partes, que estuvo tres meses y medio, ansy en cobrar los testimonyos en Nápoles como en Cecilia, que le hizo detener el Visorrey de Cecilia para enbiarle otra vez a Túnez por cosas que tocavan al servicio de S.M., aunque anduvo medio mendicando y pasó vida arto lagadra, gastó a cinco escudos por mes, que son sesenta libras y siete sueldos y seis dineros, que también al dicho dottor cabe su parte [60 libras, 7 sueldos y 6 dineros / $6.293 \mathrm{mrs}$.].

Más se le pasa en quenta que gastó el dicho fray Juan de costa de su persona y moço y cavalgadura, después que llegó en Barcelona hasta llegar en Madrid, donde presentes están los del Consejo de las Órdenes, que vino a dar esta dicha quenta, asta todo jullio del presente año de quinyentos e treynta e cinco, que estuvo quatro meses, ansy en venyr de Nápoles a Barcelona como en Barcelona y visitando la dicha su encomienda y en otras partes, negociando algunas cosas a él convinyentes, por encomendadas de tierra de moros, y en el camyno fasta venyr a Madrid, porque algunas veses no gastó a quenta de su cargo y a este respeto, como dicho es, no pone en datta por su persona y moço y cavalgadura más de cinco escudos por mes, que son sesenta y nueve libras, que también al dicho dottor cabe su ratta parte [69 libras / 7.190 mrs.].

De manera que montan los mrs. quel dicho fray Juan de Yribas a gastado y se le resciben en quenta en la manera que dicha es, quatro myll y quatrocientas y noventa libras de moneda de Génova, que valen moneda de Castilla quatrocientas y sesenta y siete myll y ochocientos y quatro mrs. [4.490 libras / 467.804 mrs.].

Alcance

De manera que alcança el dicho fray Joan de Yribas, segund paresce por la dicha quenta, por ciento y cinco myll y docientos y cinquenta $\mathrm{mrs}$. [105.250 mrs.]
Cargo que se le haze al dicho fray Juan de Yribas de lo que a valido la mercaduría que compró y llevó en nombre de los señores del Consejo de las Órdenes para redemyr los dichos cativos, como dicho es, es lo siguiente:

Cargo

Primeramente, vendyó en Túnez treynta y syete libras de oro hilado, a quinze escudos cada caxetta o libra, como estava, que son quynyentos y cinquenta y cinco escudos [555 escudos].

Que vendió tres pieças de paño de Génova florencias, a treynta escudos cada pieça, y más syete pieças por menudo cada pieça a quarenta escudos, que suman las dos partidas trezientos y setenta escudos [370 escudos].

Que vendió treynte y syete rótulos de corales, a dos escudos y medio cada rótulo, más ocho rótulos y doze onças por rescate de un cativo, a quatro escudos, que son treynta e cinco escudos, más cinco rótulos y medio de corales por rescate de otro cativo, a cinco escudos el rótulo, asy monta, contando a treynta y dos nazaros el escudo, las dichas quatro partidas de corales la suma de ciento y noventa y tres escudos y ocho nazaros [193 escudos y 8 nazaros].

Yten, que vendió el papel de extraça, la vala gruesa, que son dos valas de las de Génova, en que las quarenta valas se reduzieron a veynte balas, y se vendieron la vala gruesa a seis ducados, que son ciento y veynte escudos [120 escudos].

Yten, que vendió trezientas dozenas de bonetes berberiscos, la dozena a una abdalia de oro, que son quarenta nazaros la abdalia, que son trezientos e setenta y cinco escudos [375 escudos].

Monta el cargo que se le haze al dicho fray Joan de Yribas, en la manera que arriba está declarado, myll y seiscientos y treze escudos y ocho nazaros [1.613 escudos y 8 nazaros].

Yten, se le haze cargo de cient escudos que ovo de ganancia en docientos ducados de mercadorías qu'el dicho fray Joan dize que llevó de su monesterio [100 escudos].

\section{Datta}

Relación del discuento que da el dicho fray Juan de Yribas, lo qual se le rescibe en quenta y descargo del dicho cargo, en la manera siguiente:

Primeramente, redimyó y rescató treynta e quatro cativos contenydos en el cuaderno morisco de los del Consejo de las Órdenes, que costaron novecientos y noventa y dos escudos y ocho nazaros [992 escudos y 8 nazaros].

Que pagó por la mercaduría a los escrivanos de la Aduana y gastos menudos de la varca del Rey y bastajos y sus cavalgaduras y estimadores de la azienda y derechos de aver fatto y de la puerta de quarenta y un cativos y medio, como los otros gastos menudos, como paresce por el testimonyo, seyscientos y sesenta escudos y doze nazaros [660 escudos y 12 nazaros].

Que pagó por el cativo del manyfacto, treynta escudos, y al alcayde, seis escudos, como consta en el testimonyo de la partida de la nave, que son treynta y seis escudos [36 escudos].

Que pagó por los gastos menudos por el taraçanal y varca del Rey y la puente de la Goleta y vastajos o guardas, de quarenta y dos cativos, etcétera, ochenta y syete escudos y veynte e quatro nazaros [87 escudos y 24 nazaros].

Que gastó en el seguimiento del pleyto de Valentín de Policasto cativo rescatado, que los moros por fuerça me lo 
tomaron en Tunes, en dar presentes y seguir el pleyto, en corales, cinco rótulos, que valieron a dos escudos y medio el rótulo y en dinero tres escudos, que son por todos quinze escudos y diez y seis nazaros [15 escudos y 16 nazaros].

De manera que alcança el dicho fray Joan a la limosna setenta y ocho escudos y veynte nazaros, que monta a moneda de Castilla veynte e ocho myll y docientos y sesenta y cinco mrs. [78 escudos y 20 nazaros / 28.265 mrs.].

Los quales dichos.XXIIIMDXV. se an de discontar .XXIIM. que caben a pagar por rata al dottor Arcilia de las costas e gastos de .CCLXX. escudos suyos, que llevó el dicho fray Juan para rescatar otros ciertos cativos, que, fechos mercadoría, montaron .DXVII. escudos, de manera que queda el dicho alcance en .CXIMDXV. [111.115 mrs.]

Alcance final

Yten, a de aver el dicho fray Joan .XX. ducados de oro que nos le mandamos dar para ayuda a los gastos de la venyda e buelta a su casa, de manera que monta todo lo que a de aver .CXIXMXV. [119.015 mrs.].

Los quales dichos .CXIXMXV. le mandamos librar e le fueron librados e pagados por Sancho de Paz, nuestro contador de las rentas e limosnas pertenescientes a la dicha redención de cativos de la dicha Orden.

E agora, el dicho fray Joan de Yribas me suplicó e pidió por merced le mandase dar la dicha quenta e finyquyto della para que en todo tienpo le fuese guardada, o como la mi merced fuere, e Yo, con acuerdo de los del my Consejo, tóvelo por bien, e por la presente apruevo e confirmo la dicha quenta que de suso va yncorporada por buena y firme e verdadera y mando que valga e sea guardada al dicho fray Joan de Yribas para syenpre jamás, e que en ella ny en cosa ny en parte della le sea puesto enbaraço ny enpedimiento alguno, de lo qual le mandé dar esta my carta, librada en el dicho my Consejo, e sellada con my sello de la dicha Orden.

E por quanto Estevan Doria ginovés, estante en esta Corte, rescibió del dicho Sancho de Paz myll ducados de oro para hazer el dicho rescate, en los quales entran las tres primeras partidas contenydas en el cargo desta quenta, y el dicho Estevan Doria e su conpañya dieron las dos cédulas de cambio contenydas en el dicho cargo, de manera que el dicho Estevan Doria queda deviendo de los dichos myll ducados quinze myll mrs., entiéndase que, pagando e restituyendo los dichos .XVM., queda libre e quyto de la obligación que hizo por los dichos myll ducados.

Dada en la villa de Madrid, a diez e ocho días del mes de setienbre, año de myll e quynyentos e treynta e cinco años. El conde don García Manrique. Licenciado Luxán. El licenciado de Álava. Secretario, Guerrero.

\section{DOCUMENTO 6}

\section{[1629]}

Don Juan Fernández Cegrí y Çúñiga pide un govier[n]o u alcaldía mayor en la Nueva España.

Archivo General de Indias, Indiferente, 111, № 80.

Pasó a Flandes, donde sirvió cinco años, y en las galeras de España, quatro, y desde el de seiscientos y diez y nueve se ha ocupado como comisario de infantería española en guiar algunas compañías por comissión de S.M., en particular, el dicho año dos que se levantaron en Logroño y Tudela de
Navarra y el de 624 otras dos que se levantaron en Murcia y Valencia y el de seiscientos y veinte y cinco cotras dos que se levantaron en San Clemente y Córdoba y en 24 de setiembre de 628 le nombró S.M. por guarda mayor del marqués del Algava por desafío que tuvo con el señor conde de la Puebla en Sevilla, y antes de llegar él allá yço fuga el dicho marqués.

Y don Francisco Fernández Cegrí, su padre, fue veynte y quatro de la ciudad de Granada y el año de quinientos y veinte y cinco sirvió en la Jornada que el marqués de Mondéjar yço al Peñón de Vélez, donde se perdió y quedó cautibo en poder del rey de Vélez de la Gomera, el qual, por ser deudo suyo, hiço mucha ynstancia con él para que se volbiese moro y porque lo hiciesse le ofreció cassar con su hermana y, biendo que no lo podía conseguir con promessas, le tuvo preso mucho tiempo y le hizo muchas amenazas, hasta sacarle tres bezes al suplicio de la muerte, y estuvo cautibo diez y ocho años, haziendo a todo resistencia, hasta que por orden del Emperador, nuestro señor, que sea en gloria, fue rescatado por un gran precio, en que entró un moro que tenía en rehenes el Rey de Portugal; después se halló en la Jornada de Túnez y en la que se ofreció contra los franceses, de que fue capitán general don Álbaro Vazán, el qual le nombró por capitán de los galeones que salieron de Galicia y de seis caravelas que salieron de aquel Reyno; y después se halló con sus armas, cavallo y criados en la guerra y levantamiento de los moriscos del Reyno de Granada, donde sirvió muy abentajadamente y con valor, cerca de las personas del señor don Juan de Austria, marqués de Mondéjar, duque de Sesa y marqués de los Vélez, haciéndose mucho casso de su persona y era llamado a los consejos de guerra que se hacían y lo hizo con general aprovación suya, haciendo valerosos hechos y que se tuvo por cierto haver sido gran parte y poderse atribuir a ellos la redución de la dicha revelión, y en carta que la dicha ciudad de Granada escrivió a S.M. en 3 de diciembre de 618 refiere los dichos servicios y dice que en la Jornada de Túnez el dicho don Francisco fue maestro de campo de un Tercio de españoles y muchos años veinte y quatro de la dicha ciudad y corregidor de Valladolid y otras partes, con haprovación.

Y que el dicho don Juan a ymitado al dicho su padre en las ocassiones que se an ofrecido, y por ello suplico a S.M. se sirviese de honrarle y hacerle merced, pues servicios de tanta satisfación y grande exenplo le obligava a suplicárselo.

\section{BibLIOgRAFÍA}

Alonso Acero, B. 2000. Orán-Mazalquivir, 1589-1639. Una sociedad española en la frontera de Berbería. Madrid: CSIC.

Bustos Rodríguez, M. 1992. "Origen y consolidación de las élites gaditanas en la época moderna», en Actas de las $X$ Jornadas de Andalucía y América: 171-187. Huelva: Diputación.

Cervantes, M. de. 1998. Don Quijote de la Mancha, ed. por Francisco Rico. Barcelona: Instituto Cervantes.

Díaz Bravo, fray J. V. 1956. Memorias históricas de Tudela. Pamplona.

García Pedraza, A. 1995. «La asimilación del morisco don Gonzalo Fernández el Zegrí. Edición y análisis de su testamento». Al-Qantara. Revista de Estudios Árabes 16-1: 41-58.

González Arévalo, R. 2004. «Reflexiones en torno al cautiverio y la esclavitud en Málaga a fines de la Edad Media». Studia Historica. Historia Medieval 22: 91-108.

González Arévalo, R. 2006a. La esclavitud en Málaga a fines de la Edad Media. Jaén: Universidad. 
González Arévalo, R. 2006b. El cautiverio en Málaga a fines de la Edad Media. Málaga: Diputación.

López de Coca, J. E. 1978. «Esclavos, alfaqueques y mercaderes en la frontera del mar de Alborán (1490-1516)». Hispania 139: 275-300.

López de Coca, J. E. 1993. "Vélez de la Gomera y su puerto durante la primera mitad del siglo XVI». Historia. Instituciones. Documentos 20: 213-223.

López de Coca, J. E. 1997. "Consideraciones sobre la frontera marítima», en Actas del Congreso la Frontera Oriental Nazarí como sujeto histórico (siglos XIII-XVI): 391-408. Almería.

Madrid Medina, Á. 2014. «El desaparecido Hospital de los Caballeros de Santiago de Toledo». Revista de la CECEL 14: 47-70.

Martínez Torres, J. A. 2004. Prisionero de los infieles. Vida y rescate de los cautivos cristianos en el Mediterráneo Musulmán (siglos XVIxVII). Barcelona: Bellaterra.

Martínez Torres, J. A. (ed.). 2008. Circulación de personas e intercambios comerciales en el Mediterráneo y en el Atlántico (siglos XVI, xVII y XVIII). Madrid: CSIC.

Medrano, G. de 1627. La Regla y Establecimientos de la Cavallería de Santiago del Espada, con la Historia del origen y principio della, compuesta por el Lcdo. don ... Madrid (reimpresión Valladolid, 1991)
Porras Arboledas, P. A. 1997. La Orden de Santiago en el siglo XV. La Provincia de Castilla, Madrid [primera edición reprografiada, en Madrid, UCM, 1981]. Disponible en eprints.ucm.es/31066/1/ Arboledas.pdf

Porras Arboledas, P. A. 2013. «Penitencias a comendadores y caballeros santiaguistas impuestas en el Capítulo general de Valladolid de 1527». Revista de las Órdenes Militares 7: 175-203.

Porras Arboledas, P. A. 2014. «Licencias concedidas por el Consejo de Órdenes para pedir limosna en sus territorios a fin de redimir cautivos (1528-1530)». Revista de las Órdenes Militares 8: 181-223.

Porras Arboledas, P. A. 2015. «Privilegios reales de la Orden de la Merced en Castilla (1289-1500) y la Orden de Santiago». Cuadernos de Historia del Derecho 22: 319-358.

Sepúlveda, J. G. de. 1998. Obras completas. IV. Historia de Felipe II, Rey de España. Pozoblanco (Córdoba).

Serrano, E. y Gómez Vozmediano, M. F. 2013. «Imprenta, dinero y fe: la impresión de bulas en el convento dominico de San Pedro Martír de Toledo (1483-1600)». Tiempos Modernos 27: 1-65.

Soria Mesa, E. 1992. «De la conquista a la asimilación. La integración de la aristocracia nazarí en la oligarquía granadina. Siglos XV-XVII». Áreas. Revista Internacional de Ciencias Sociales 14: 51-64. 